\title{
Praktyka orzecznicza sądów administracyjnych w zakresie spraw dotyczących sztucznego tworzenia warunków do przyznania płatności przez Agencję Restrukturyzacji i Modernizacji Rolnictwa
}

\section{Wstęp}

Realizacja programów unijnych mających na celu wsparcie finansowe dla określonych grup zawodowych i społecznych wiąże się nie tylko z wypłatą środków, ale także z weryfikacją prawidłowości ich udzielenia. Kontrole w zakresie spełniania warunków do przyznania płatności odbywają się oczywiście przed jej przyznaniem, ale tak naprawdę podmiot wypłacający środki nie jest w stanie zweryfikować wszystkich złożonych wniosków pod kątem stworzenia sztucznych warunków. Oczywiście już w ramach wstępnej kontroli formalnej wniosku można zauważyć, że nie spełnia on warunków do pozytywnego rozpatrzenia. Po etapie sprawdzenia formalnych wymogów wniosku sprawdza się, czy spełniono materialne przesłanki wymagane do przyznania płatności. Narzędzia, jakie posiada organ płatniczy, pozwalają w dużej mierze na wykrycie nieprawidłowości, które uniemożliwiają przyznanie płatności w części lub w całości. Niestety zdarzają się sprawy, w których - czy to na podstawie przeprowadzonej weryfikacji wniosku, czy też doniesienia o podejrzeniu popełnienia nadużycia, czy wreszcie z powodu samych zainteresowanych, którzy składają wnioski wzajemnie się wykluczające - stwierdzone zostaje stworzenie sztucznych warunków do przyznania płatności przez agencję płatniczą. Nierzadko informacja o nadużyciu pojawia się kilka lat po przyznaniu tych płatności i przed organami Agencji Restrukturyzacji i Modernizacji Rolnictwa (ARiMR) pojawia się perspektywa ciągnących się przez długie lata postępowań administracyjnych i sądowoadministracyjnych.

Przeprowadzenie w ramach postępowania wyjaśniającego dowodów na potwierdzenie wystąpienia nadużycia wiąże się z czasochłonnym zaangażowaniem kadry pracowniczej, która skrupulatnie musi przedstawić krok po kroku cały proceder wyłudzenia płatności. Opisanie okoliczności sprawy,

\footnotetext{
${ }^{1}$ Dr Tomasz Kalita, Agencja Restrukturyzacji i Modernizacji Rolnictwa.
} 
przeprowadzenie dowodów, postawienie zarzutów, wszczęcie zamkniętych postępowań, wydanie nowych decyzji w postępowaniu administracyjnym, wszczęcie postępowań windykacyjnych i wreszcie przebrnięcie przez etap postępowań sądowoadministracyjnych wymaga uwagi i pracy wielu osób.

Przedstawiona poniżej analiza stanów faktycznych i prawnych spraw prowadzonych już na poziomie sądów administracyjnych pokaże nie tylko, jak z praktycznej strony wygląda prowadzenie obsługi wniosku o przyznanie płatności, ale też jaką specjalistyczną wiedzę należy posiadać, by móc zajmować się tego typu sprawami. Paradoksalnie można także stwierdzić, że niniejszy artykuł wskazuje, jaki zasób wiedzy posiadali wyłudzający płatności lub jakimi pokładami informacji dysponowały osoby im doradzające.

Celem tekstu jest przedstawienie i analiza mechanizmów, jakie zostają wykorzystane do wyłudzenia płatności poprzez wykorzystanie luk prawnych i stworzenie sztucznych warunków do przyznania finansowego wsparcia. Może być on przydatny nie tylko dla pracowników ARiMR lub innych agencji płatniczych, ale też dla asystentów i sędziów sądów administracyjnych, przed którymi postawiono wyzwanie dokonania rozstrzygnięcia sprawy o podobnej problematyce, oraz dla organów ścigania, które prowadzą postępowania w zakresie wyłudzeń unijnych dotacji i płatności.

W tekście wykorzystano przede wszystkim metodę analitycznoprawną oraz dogmatyczną. Rozważania oparto na analizie obowiązujących przepisów prawnych i orzeczeń sądowych oraz poglądów przedstawicieli nauki prawa administracyjnego, przywołano także przepisy prawa unijnego i krajowego, które przestały już obowiązywać, ale ich przedstawienie było niezbędne do nakreślenia sposobów wyłudzeń płatności, motywacji sprawców, a także określenia działań podejmowanych przez organy ARiMR i sądy administracyjne.

\section{Legalna definicja nieprawidłowości i obowiązek dowodowy w postępowaniu administracyjnym}

W preambule do rozporządzenia Rady (WE, EURATOM) nr 2988/95 z dnia 18 grudnia 1995 r. w sprawie ochrony interesów finansowych Wspólnot Europejskich ${ }^{2}$ zaznaczono, że prawo wspólnotowe nakłada na Komisję Europejską i państwa członkowskie obowiązek badania, czy środki z budżetu Wspólnoty są wykorzystywane zgodnie z ich przeznaczeniem. Rozporządzenie to statuuje ogólne zasady dotyczące jednolitych kontroli oraz środków administracyjnych i kar za nieprawidłowości w odniesieniu do prawa wspólnotowego ${ }^{3}$. „Nieprawidłowości” zostały zdefiniowane

\footnotetext{
${ }^{2}$ Dz. Urz. UE L 312, s. 1.

${ }^{3}$ Art. 1 ust. 1 rozporządzenia nr 2988/95. Por. P. Wojciechowski, Odpowiedzialność administracyjna i karna beneficjentów pomocy z Programu Rozwoju Obszarów Wiejskich, „Studia Iuridica Agraria” 2012, t. X, s. 290-291.
} 
jako jakiekolwiek naruszenie przepisów prawa wspólnotowego wynikające $\mathrm{z}$ działania lub zaniedbania ze strony podmiotu gospodarczego, które spowodowało lub mogło spowodować szkodę w ogólnym budżecie Wspólnot lub w budżetach, które są zarządzane przez Wspólnoty, albo poprzez zmniejszenie lub utratę przychodów, które pochodzą ze środków własnych pobieranych bezpośrednio w imieniu Wspólnot, albo też w związku z nieuzasadnionym wydatkiem ${ }^{4}$.

Kontrole administracyjne oraz środki i kary w tym zakresie wprowadzone zostały dla zapewnienia właściwego stosowania prawa unijnego, z zastrzeżeniem, że mają być skuteczne, proporcjonalne i odstraszające w celu zapewnienia odpowiedniej ochrony interesów finansowych Wspólnot $^{5}$. Zgodnie z art. 2 ust. 4 rozporządzenia 2988/95 przyjęto, że procedury dotyczące zastosowania wspólnotowych kontroli, środków i kar będą podlegały prawu państw członkowskich 6 .

Państwo członkowskie, na podstawie art. 4 ust. 3 rozporządzenia nr 2988/95, a także art. 30 rozporządzenia Rady (WE) nr 73/2009 z dnia 19 stycznia 2009 r. ustanawiającego wspólne zasady dla systemów wsparcia bezpośredniego dla rolników w ramach wspólnej polityki rolnej i ustanawiającego określone systemy wsparcia dla rolników, zmieniającego rozporządzenia (WE) nr 1290/2005, (WE) nr 247/2006, (WE) nr 378/2007 oraz uchylającego rozporządzenie (WE) $\mathrm{nr} 1782 / 2003^{7}$ oraz art. 4 ust. 8 rozporządzenia Komisji (UE) nr 65/2011 z dnia 27 stycznia 2011 r. ustanawiającego szczegółowe zasady wykonania rozporządzenia Rady (WE) nr 1698/2005 w odniesieniu do wprowadzenia procedur kontroli oraz do zasady wzajemnej zgodności $\mathrm{w}$ zakresie środków wsparcia rozwoju obszarów wiejskich ${ }^{8}$, sprawdza m.in., czy nie zostały stworzone sztuczne warunki w celu uzyskania korzyści sprzecznych z celami wsparcia. Rozporządzenia $\mathrm{nr} 73 / 2009$ oraz 65/2011 co do zasady obowiązywały przed 1 stycznia 2015 r., lecz analogiczne rozwiązania zostały zawarte $\mathrm{w}$ rozpo-

${ }^{4}$ Art. 1 ust. 2 rozporządzenia nr 2988/95.

${ }^{5}$ Art. 2 ust. 1 rozporządzenia nr 2988/95. Z uwagi na temat artykułu autor skupił się wyłącznie na administracyjnych i sądowoadministracyjnych postępowaniach dotyczących sztucznego tworzenia warunków do przyznania płatności przez ARiMR. Odrębnym zagadnieniem są natomiast karnoprawne aspekty zjawiska wyłudzenia płatności, o czym szerzej: Z. Kukuła, Karnoprawna ocena płatności bezpośrednich w polskim rolnictwie. Glosa do postanowienia z dnia 19 maja 2011 r. (I KZP 3/11), „Przegląd Sądowy" 2012, nr 1, s. 126-131; M. Strzelecki, O kryminalistycznych aspektach wyłudzania płatności bezpośrednich i uzupełniajacych $w$ świetle badań aktowych, „Prokuratura i Prawo" 2014, nr 6, s. 148-166.

${ }^{6} \mathrm{O}$ kontroli wydatków agencji płatniczych, a także o skuteczności stosowanych w Polsce rozwiązań w zakresie ochrony interesów finansowych Unii Europejskiej w dziedzinie Wspólnej Polityki Rolnej zob. J. Stoksik, Wybrane zagadnienia ochrony interesów finansowych Unii Europejskiej w dziedzinie wspólnej Polityki Rolnej, „Studia Iuridica Agraria” 2012, t. X, s. 436-439.

${ }^{7}$ Dz. Urz. UE L 30, s. 16 ze zm.

${ }^{8}$ Dz. Urz. UE L 25, s. 8 ze zm. 
rządzeniu Parlamentu Europejskiego i Rady (UE) nr 1306/2013 z dnia 17 grudnia 2013 r. w sprawie finansowania wspólnej polityki rolnej, zarządzania nią i monitorowania jej oraz uchylającym rozporządzenia Rady (EWG) nr 352/78, (WE) nr 165/94, (WE) nr 2799/98, (WE) nr 814/2000, (WE) nr 1290/2005 i (WE) nr 485/20089 oraz rozporządzeniu Parlamentu Europejskiego i Rady (UE) nr 1307/2013 z dnia 17 grudnia 2013 r. ustanawiającym przepisy dotyczące płatności bezpośrednich dla rolników na podstawie systemów wsparcia w ramach wspólnej polityki rolnej oraz uchylającym rozporządzenie Rady (WE) nr 637/2008 i rozporządzenie Rady (WE) nr $73 / 2009^{10}$.

Zgodnie z art. 4 ust. 3 rozporządzenia nr 2988/95 działania skierowane na pozyskanie korzyści w sposób sprzeczny z odpowiednimi celami prawa wspólnotowego mającymi zastosowanie w danym przypadku poprzez sztuczne stworzenie warunków w celu uzyskania tej korzyści prowadzą do nieprzyznania lub wycofania korzyści. Artykuł 30 rozporządzenia nr 73/2009 stanowi, że nie naruszając szczególnych przepisów odnoszących się do poszczególnych systemów wsparcia, nie dokonuje się żadnych płatności na rzecz beneficjentów, w odniesieniu do których ustalono, że sztucznie stworzyli warunki wymagane do otrzymania takich płatności, aby uzyskać korzyści sprzeczne z celami danego systemu wsparcia. Analogiczne rozwiązanie przewidziano $\mathrm{w}$ art. 60 rozporządzenia nr 1306/2013, przyjmując, że osobom fizycznym ani prawnym nie przyznaje się jakichkolwiek korzyści wynikających z sektorowego prawodawstwa rolnego, jeżeli stwierdzono, że warunki wymagane do uzyskania takich korzyści zostały sztucznie stworzone, w sprzeczności z celami tego prawodawstwa. Zarówno art. 30 rozporządzenia $\mathrm{nr} 73 / 2009$, art. 4 ust. 8 rozporządzenia $\mathrm{nr} 65 / 2011$, jak i art. 60 rozporządzenia nr 1306/2013 stanowią lex specialis w stosunku do art. 4 ust. 3 rozporządzenia nr 2988/95.

W art. 3 ust. 3 ustawy z dnia 26 stycznia 2007 r. o płatnościach w ramach systemów wsparcia bezpośredniego 11 i art. 21 ust. 3 ustawy z dnia 7 marca 2007 r. o wspieraniu rozwoju obszarów wiejskich z udziałem środków Europejskiego Funduszu Rolnego na rzecz Rozwoju Obszarów Wiejskich ${ }^{12}$ wskazano, że strony oraz inne osoby uczestniczące w postępowaniu są obowiązane przedstawiać dowody oraz dawać wyjaśnienia co do okoliczności

${ }^{9}$ Dz. Urz. UE L 347, s. 549 ze zm.

${ }^{10}$ Dz. Urz. UE L 347, s. 608 ze zm.

${ }^{11}$ Tekst jedn.: Dz.U. z 2012 r. poz. 1164 ze zm. Odpowiednik tego przepisu znajduje się w art. 3 ust. 3 obowiązującej ustawy z dnia 5 lutego 2015 r. o płatnościach w ramach systemów wsparcia bezpośredniego, tekst jedn.: Dz.U. z 2017 r. poz. 278 ze zm.

12 Tekst jedn.: Dz.U. z 2017 r. poz. 1856 ze zm. Odpowiednik tego przepisu znajduje się w art. 27 ust. 2 obowiązującej ustawy z dnia 20 lutego 2015 r. o wspieraniu rozwoju obszarów wiejskich z udziałem środków Europejskiego Funduszu Rolnego na rzecz Rozwoju Obszarów Wiejskich w ramach Programu Rozwoju Obszarów Wiejskich na lata 2014-2020, tekst jedn.: Dz.U. z 2017 r. poz. 562 ze zm. 
sprawy zgodnie z prawdą i bez zatajania czegokolwiek, a ciężar udowodnienia faktu spoczywa na osobie, która z tego faktu wywodzi skutki prawne ${ }^{13}$. Dokonana w art. 3 ust. 3 ustawy z 2007 r. o płatnościach w ramach systemów wsparcia bezpośredniego modyfikacja zasad dowodzenia nie może być jednak pojmowana jako niczym nieograniczony obowiązek strony prezentacji i oferowania dowodów potwierdzających jej twierdzenia ${ }^{14}$. Oznacza ona, że na organie istotnie nie ciąży obowiązek aktywnego poszukiwania dowodów mających wspierać stanowisko strony, jednak w związku z jej twierdzeniami i zarzutami organ powinien zgromadzić takie dowody, które pozwoliłyby na zweryfikowanie ich prawdziwości ${ }^{15}$. Konieczność odniesienia się do wszystkich zarzutów strony, a zwłaszcza takich, których rozpatrzenie mogłoby mieć wpływ na treść rozstrzygnięcia, jednoznacznie wynika $z$ treści art. $107 \$ 3$ k.p.a. ${ }^{16}$, natomiast określone w art. 3 ust. 3 powyższej ustawy przerzucenie ciężaru dowodu nie może prowadzić do naruszenia przez organ obowiązku przestrzegania zasady praworządności, w której mieści się również obowiązek oparcia rozstrzygnięcia na stanie faktycznym zgodnym $\mathrm{z}$ rzeczywistością ${ }^{17}$.

W myśl art. $77 \$ 1$ k.p.a. organ administracji publicznej jest obowiązany w sposób wyczerpujący zebrać i rozpatrzyć cały materiał dowodowy ${ }^{18}$. Natomiast art. 80 k.p.a. stanowi, że organ administracji publicznej ocenia na podstawie całokształtu materiału dowodowego, czy dana okoliczność została udowodniona. Stosownie do tych przepisów organ admini-

${ }^{13}$ Zob. wyrok WSA w Gdańsku z dnia 25 czerwca 2013 r., I SA/Gd 391/13; wyrok WSA w Łodzi z dnia 14 stycznia 2014 r., III SA/Łd 1007/13; wyrok WSA w Krakowie z dnia 18 lutego 2014 r., III SA/Kr 778/13; wyrok WSA w Krakowie z dnia 12 sierpnia 2014 r., III SA/Kr 6/14; wyrok NSA z dnia 11 marca 2015 r., II GSK 134/14; wyrok WSA we Wrocławiu z dnia 6 maja 2015 r., III SA/Wr 844/14; wyrok NSA z dnia 4 września 2015 r., II GSK 1636/14; wyrok NSA z dnia 28 października 2015 r., II GSK 1884/14; wyrok WSA w Olsztynie z dnia 3 grudnia 2015 r., I SA/Ol 639/15; wyrok WSA w Rzeszowie z dnia 7 marca 2016 r., I SA/Rz 1100/15 - jeżeli nie zaznaczono inaczej wszystkie wszystkie wyroki dostępne są na stronie CBOSA.

${ }^{14}$ Zob. szerzej: wyrok WSA w Gdańsku z dnia 9 grudnia 2015 r., I SA/Gd 1426/15, CBOSA; M. Peisert, Szczególne postępowanie administracyjne w sprawach o przyznanie płatności w ramach systemów wsparcia bezpośredniego rolnictwa - zarys problematyki, „Zeszyty Naukowe Sądownictwa Administracyjnego" 2011, nr 1 (34), s. 37-48.

${ }^{15}$ Zob. wyrok WSA w Gdańsku z dnia 9 grudnia 2015 r., I SA/Gd 1426/15.

${ }^{16}$ Ustawa z dnia 14 czerwca 1960 r. - Kodeks postępowania administracyjnego, Dz.U. z 2017 r. poz. 1257 ze zm.

${ }^{17}$ Wyrok WSA w Gdańsku z dnia 9 grudnia 2015 r., I SA/Gd 1426/15.

${ }^{18}$ Zob. szerzej: B. Adamiak, Obowiązek organu administracji publicznej rozpatrzenia całego materiału dowodowego [w:] Kodeks postępowania administracyjnego. Komentarz, Warszawa 2006, s. 406-407; C. Martysz, Komentarz do art. 77 Kodeksu postępowania administracyjnego [w:] G. Łaszczyca, C. Martysz, A. Matan, Kodeks postępowania administracyjnego. Komentarz, t. I, Komentarz do art. 1-103, LEX 2010; M. Jaśkowska, A. Wróbel, Komentarz aktualizowany do Kodeksu postępowania administracyjnego, LEX 2015. 
stracji państwowej jest zobowiązany przeanalizować z osobna, jak i w ich wzajemnym powiązaniu każdy z dowodów zebranych w sprawie. Przepis art. 80 k.p.a. nie wyznacza organowi administracji publicznej merytorycznych reguł oceny wyników postępowania dowodowego, co skłania doktry$n^{19}{ }^{19}$ orzecznictwo do konkluzji, że przepis ten statuuje zasadę swobodnej oceny dowodów. Zasada ta polega na tym, „by organ przy ustalaniu prawdy na podstawie materiału dowodowego nie był skrępowany żadnymi przepisami co do wartości poszczególnych rodzajów dowodów i mógł swobodnie, tj. zgodnie z własną oceną wyników postępowania dowodowego (wyjaśniającego) w danej sprawie ustalić stan faktyczny" ${ }^{20}$. Stosownie do art. 3 ust. 1 ustawy z 2007 r. o płatnościach w ramach systemu wsparcia bezpośredniego w sprawach indywidualnych rozstrzyganych $\mathrm{w}$ drodze decyzji stosuje się przepisy Kodeksu postępowania administracyjnego, chyba że przepisy ustawy stanowią inaczej. W art. 3 ust. 2 tej ustawy zostały wskazane zasady ogólne postępowania w sprawie przyznania płatności sformułowane odmiennie niż w Kodeksie. Zgodnie $\mathrm{z}$ tym przepisem organ ma obowiązek rozpatrzenia całego materiału dowodowego w sposób wyczerpujący, udzielania pouczeń stronom na ich wniosek, a także zapewnienia stronom czynnego udziału w postępowaniu na ich żądanie ${ }^{21}$. Z tego przepisu wynika, że ustawodawca zdecydował się na odejście od niektórych zasad ogólnych postępowania administracyjnego wyrażonych w Kodeksie postępowania administracyjnego, a także dokonał ich modyfikacji np. w odniesieniu do zasad: prawdy obiektywnej, informowania stron oraz zapewnienia stronom czynnego udziału w postępowaniu ${ }^{22}$.

Z zasady dwuinstancyjności postępowania administracyjnego zawartej w art. 15 k.p.a. wynika obowiązek dwukrotnego merytorycznego rozstrzygnięcia tej samej sprawy przez dwa różne organy administracji. Natomiast zgodnie z art. 136 k.p.a. organ odwoławczy może przeprowadzić na swoim etapie postępowanie dowodowe, jednakże jego zakres nie może być zbyt szeroki, a jedynie ma mieć charakter uzupełniający ${ }^{23}$. W związku z tym do istoty zasady dwuinstancyjności postępowania należy nakaz dwukrotnego rozpatrywania sprawy, rozumiany jako konieczność rozważenia materiału dowodowego najpierw przez organ I instancji, a następnie przez organ odwoławczy. Zasadą jest skoncentrowanie postępowania dowodowego

${ }^{19}$ J. Bieluk, D. Joanna Łobos-Kotowska, Komentarz do art. 3 ustawy o płatnościach $w$ ramach systemów wsparcia bezpośredniego [w:] Ustawa o płatnościach w ramach systemów wsparcia bezpośredniego. Komentarz, LEX 2008.

${ }^{20}$ E. Iserzon, J. Starościak, Kodeks postępowania administracyjnego. Komentarz (teksty, wzory i formularze), Warszawa 1970, s. 155.

${ }^{21}$ Zob. wyrok NSA z dnia 6 lipca 2016 r., II GSK 511/15.

${ }^{22}$ Ibidem.

${ }^{23}$ Zob. B. Adamiak, Forma zakończenia postępowania wstępnego organu odwoławczego [w:] B. Adamiak, J. Borkowski, Kodeks postępowania administracyjnego. Komentarz, Warszawa 2006, s. 602-603. 
w ramach postępowania pierwszoinstancyjnego. Organ II instancji jest uprawniony wyłącznie do przeprowadzenia uzupełniającego postępowania dowodowego. Ponadto należy zwrócić uwagę, iż przepis art. 107 \$ 1 k.p.a. wskazuje, jakie elementy powinna zawierać decyzja administracyjna. Zgodnie z jego treścią decyzja powinna zawierać m.in. powołanie podstawy prawnej oraz uzasadnienie faktyczne i prawne. Przepis w $₫ 3$ stanowi, iż uzasadnienie faktyczne decyzji powinno w szczególności zawierać wskazanie faktów, które organ uznał za udowodnione, dowodów, na których się oparł, oraz przyczyn, z powodu których innym dowodom odmówił wiarygodności i mocy dowodowej, zaś uzasadnienie prawne - wyjaśnienie podstawy prawnej decyzji z przytoczeniem przepisów prawa.

Poprawność wydania decyzji przez organ I i II instancji w sytuacji wniesienia skargi przez producenta rolnego podlega ocenie sądów administracyjnych: Wojewódzkiego Sądu Administracyjnego i Naczelnego Sądu Administracyjnego ${ }^{24}$. Analiza wyroków kończących postępowania sądowoadministracyjne w sprawach z zakresu sztucznego tworzenia warunków do uzyskania płatności przez ARiMR zostanie przedstawiona w pkt 4 niniejszego artykułu.

\section{Analiza pojęcia sztucznych warunków}

Materialnoprawną podstawę zaskarżonych w analizowanych sprawach rozstrzygnięć stanowił art. 4 ust. 8 rozporządzenia nr 65/2011, zgodnie z którym nie dokonuje się żadnych płatności na rzecz beneficjentów, w odniesieniu do których ustalono, że sztucznie stworzyli warunki wymagane do otrzymania takich płatności, aby uzyskać korzyści sprzeczne z celami

${ }^{24}$ Zgodnie z art. 184 Konstytucji RP z dnia 2 kwietnia 1997 r. (Dz.U. Nr 78 poz. 483 ze zm.) Naczelny Sąd Administracyjny oraz inne sądy administracyjne sprawują, w zakresie określonym w ustawie, kontrolę działalności administracji publicznej. Do $2004 \mathrm{r}$. NSA był jedynym sądem administracyjnym i działał w ramach zasady jednoinstancyjności. Od 1 stycznia 2004 r. organami pierwszej instancji są wojewódzkie sądy administracyjne, a NSA jest sądem drugiej instancji. Sądy te działają na podstawie ustawy Prawo o ustroju sądów administracyjnych (tekst jedn.: Dz.U. z 2017 r. poz. 2188 ze zm.) i ustawy - Prawo o postępowaniu przed sądami administracyjnymi (tekst jedn.: Dz.U. z 2018 r. poz. 1302). Obowiązujące obecnie przepisy prawne przewidują generalną zasadę skargi sądowej. Klauzula generalna obejmuje wszystkie decyzje administracyjne z nielicznymi wyjątkami. Tak więc zaskarżana może być do sądu administracyjnego każda decyzja administracyjna pod zarzutem jej niezgodności z prawem, o ile nie została wyłączona z mocy ustawy. Skargę na decyzję administracyjną wnosi się do sądu po wyczerpaniu toku instancji w postępowaniu administracyjnym, jednakże prokurator nie jest ograniczony tym postanowieniem i może wnieść skargę na każdą decyzję. Skargę ma prawo wnieść każdy, kto ma w tym interes prawny, z prawa tego korzysta także prokurator, Rzecznik Praw Obywatelskich i organizacje społeczne. Zob. W. Skrzydło, Komentarz do art. 184 Konstytucji Rzeczypospolitej Polskiej [w:] Konstytucja Rzeczypospolitej Polskiej. Komentarz, Warszawa 2013, s. 195; P. Daniel, Prawa i obowiązki organu administracji w postępowaniu sądowoadministracyjnym, Wrocław 2014, s. 17-40. 
danego systemu wsparcia. Przepis ten zawierał generalną klauzulę pozwalającą organom administracji publicznej przeciwdziałać obejściu prawa w celu uzyskania korzyści wbrew intencjom ustawodawcy unijnego. Analizowane obejście prawa dotyczy sytuacji, w których działanie danej osoby zmierza do innego niż typowe $\mathrm{w}$ danych okolicznościach, wynikających z przepisów prawa, ukształtowania stosunków faktycznych lub prawnych w celu osiągnięcia zamierzonego przez taką osobę skutku prawnego.

Za tworzenie sztucznych warunków uważa się m.in. sztuczny podział gospodarstwa rolnego na kilka mniejszych, dokonany w celu zawyżenia przysługującej pojedynczemu rolnikowi kwoty płatności bezpośrednich, płatności rolnośrodowiskowych, pomocy finansowej z tytułu wspierania gospodarowania na obszarach górskich i innych obszarach o niekorzystnych warunkach gospodarowania (ONW) oraz płatności na zalesianie gruntów rolnych (w związku z ominięciem limitu powierzchni i degresywności stawek płatności).

Podejrzenie stworzenia sztucznych warunków może pojawić się m.in. w przypadku podziału gospodarstwa rolnego na kilka mniejszych, w szczególności poprzez tworzenie wielu spółek powiązanych ze sobą osobowo i kapitałowo dla uzyskania płatności w odniesieniu do gruntów, które faktycznie są w posiadaniu jednego podmiotu lub są przedmiotem współposiadania, występowanie oddzielnie o przyznanie płatności przez podmioty będące faktycznie współposiadaczami gruntów czy też posługiwanie się przez podmioty tym samym numerem rachunku bankowego.

Zgodnie z wyrokiem WSA w Warszawie z dnia 20 grudnia $2011 \mathrm{r}$., V SA/Wa 1659/11 organy administracji są zobowiązane do badania, czy stosunki między podmiotami gospodarczymi nie są układane w sposób sztuczny w celu uzyskania korzyści finansowej, której jeden z podmiotów nie mógłby uzyskać samodzielnie. Sąd w wyroku stwierdził, że jakkolwiek panuje swoboda układania stosunków gospodarczych, to jednak organy administracji są zobowiązane do badania, czy stosunki te nie są układane w sposób sztuczny i w razie stwierdzenia takiego faktu organ powinien odmówić przyznania dofinansowania.

Należy zauważyć, że obejście i nadużycie prawa nie może skutkować ochroną prawną podmiotu, który sztucznie kreuje okoliczności uzasadniające stosowanie danej normy przyznającej określoną korzyść finansową i wiąże się to $\mathrm{z}$ sankcją wykluczenia możliwości skorzystania $\mathrm{z}$ tego prawa przez ten podmiot, o czym orzekł Trybunał Sprawiedliwości UE w wyroku z dnia 16 marca 2006 r. w sprawie C-94/05, Emsland-Stärke GmbH przeciwko Landwirtschaftskammer Hannover ${ }^{25}$, pkt 52-53.

Rozporządzenie nr 65/2011 nie definiuje ściśle pojęcia sztucznych warunków ${ }^{26}$, dlatego też sądy krajowe posłużyły się wykładnią zawartą

${ }^{25}$ ECR 2006, nr 3A, s. I-2619.

${ }^{26} \mathrm{~W}$ obowiązującym rozporządzeniu nr 1307/2013 także nie zdecydowano się na doprecyzowanie tego pojęcia. 
w wyroku Trybunału Sprawiedliwości z dnia 12 września 2013 r. w sprawie C-434/12, Stynczewa siła EOOD v. Izpylnitelen direktor na Dyrżawen fond "Zemedelie” - Razplasztatelna agencija ${ }^{27}$. Wyrok w tej sprawie określa prawidłowy sposób postępowania przez organy ARiMR przy ocenie wystąpienia przesłanek $\mathrm{z}$ art. 4 ust. 8 rozporządzenia nr 65/2011. Trybunał orzekł, że do stwierdzenia stworzenia przez beneficjenta sztucznych warunków uzasadniających odmowę przyznania płatności konieczne jest wykazanie łącznego wystąpienia elementu obiektywnego (ogółu obiektywnych okoliczności, z których wynika, że pomimo formalnego poszanowania przesłanek przewidzianych $\mathrm{w}$ stosownych uregulowaniach cel realizowany przez te uregulowania nie został osiągnięty) i subiektywnego (wola uzyskania korzyści wynikającej z uregulowań Unii Europejskiej poprzez sztuczne stworzenie wymaganych dla jej uzyskania przesłanek). W ramach istnienia elementu obiektywnego do sądów należało rozważenie obiektywnych okoliczności danego przypadku, pozwalających na stwierdzenie, że nie może zostać osiągnięty cel zamierzony przez system wsparcia Europejskiego Funduszu Rolnego na rzecz Rozwoju Obszarów Wiejskich (EFRROW). Natomiast $\mathrm{w}$ ramach drugiego z elementów (subiektywnego) do sądów należało rozważenie obiektywnych dowodów pozwalających na stwierdzenie, że poprzez sztuczne stworzenie warunków wymaganych do otrzymania płatności z systemu wsparcia EFRROW ubiegający się o taką płatność zamierzał wyłącznie uzyskać korzyść sprzeczną $\mathrm{z}$ celami tego systemu. W tym względzie sądy mogły oprzeć się nie tylko na elementach takich jak więź prawna, ekonomiczna lub personalna pomiędzy osobami zaangażowanymi w przedsięwzięcie, lecz także na wskazówkach świadczących o istnieniu zamierzonej koordynacji pomiędzy tymi osobami ${ }^{28}$.

\section{Analiza wyroków sądów administracyjnych w zakresie spraw dotyczących sztucznego tworzenia warunków}

Przeanalizowanie treści 22 orzeczeń wydanych przez NSA w 2017 r., a także zapoznanie się $\mathrm{z}$ wydanymi $\mathrm{w}$ danych sprawach zaskarżonymi wyrokami wojewódzkich sądów administracyjnych pozwoliło na wyodrębnienie trzech bloków tematycznych związanych z tą problematyką, dotyczących odpowiednio: tworzenia grup producentów, płatności zalesieniowych oraz płatności obszarowych i górskich. W ramach pierwszej grupy za istotne uznano zwrócenie uwagi na wyrok WSA w Warszawie z dnia 30 stycznia

\footnotetext{
${ }^{27}$ ZOTSiS 2013, nr 9, s. I-546.

${ }^{28}$ Zob. wyrok TS z dnia 21 lipca 2005 r. w sprawie C-515/03, Eichsfelder Schlachtbetrieb GmbH v. Hauptzollamt Hamburg-Jonas, ECR 2005, nr 7B, s. I-7355, pkt 39 i przywołane orzecznictwo; wyrok TS z dnia 11 stycznia 2007 r. w sprawie C-279/05, Vonk Dairy Products BV v. Productschap Zuivel, ECR 2007, nr 1A, s. I-239, pkt 33.
} 
2015 r., V SA/Wa 2923/1429. Stwierdzono w nim, że podmioty mogą organizować się $\mathrm{w}$ grupy producentów rolnych ${ }^{30} \mathrm{w}$ celu dostosowania produkcji rolnej do warunków rynkowych, poprawy efektywności gospodarowania, planowania produkcji ze szczególnym uwzględnieniem jej ilości i jakości, koncentracji podaży oraz organizowania sprzedaży produktów rolnych, a także ochrony środowiska naturalnego, wsparcia natomiast udziela się w celu ułatwienia tworzenia i działalności administracyjnej grup producentów celem dostosowania do wymogów rynkowych procesu produkcyjnego i produkcji producentów, którzy są członkami takich grup, wspólnego wprowadzania towarów do obrotu, w tym przygotowania do sprzedaży, centralizacji sprzedaży i dostawy do odbiorców hurtowych, ustanowienia wspólnych zasad dotyczących informacji o produkcji, ze szczególnym uwzględnieniem zbiorów i dostępności. Przepisy wskazują na cel, jakim jest ułatwienie organizowania się przez indywidualnych, samodzielnych producentów funkcjonujących na rynku (mimo braku określenia przez ustawodawcę minimalnego okresu prowadzenia działalności) w grupy umożliwiające uzyskanie lepszej pozycji konkurencyjnej takich podmiotów.

Zdaniem Sądu zaskarżony organ wskazał m.in. na: chronologię zgłoszenia rozpoczęcia działalności, datę zawiązania umowy spółki z o.o., daty umów użyczenia indyczników przez dotychczasowych producentów, powiązania rodzinne poszczególnych członków grupy, miejsce prowadzenia działalności gospodarczej, a przede wszystkim ewidentną zależność no-

${ }^{29}$ Wyrok utrzymany w mocy na podstawie wyroku NSA z dnia 12 stycznia 2017 r., II GSK 1299/15.

${ }^{30}$ Zasady dotyczące organizowania się producentów rolnych $\mathrm{w}$ grupy producentów oraz warunki udzielania ze środków publicznych pomocy finansowej związanej z ich organizowaniem i funkcjonowaniem określa ustawa z 15 września 2000 r. o grupach producentów rolnych i ich związkach oraz o zmianie innych ustaw (tekst jedn.: Dz.U. z 2018 r. poz. 1026 ze zm.). Zgodnie z art. 2 tej ustawy osoby fizyczne, jednostki organizacyjne nieposiadające osobowości prawnej oraz osoby prawne prowadzące gospodarstwo rolne w rozumieniu przepisów o podatku rolnym lub prowadzące działalność rolniczą w zakresie działów specjalnych produkcji rolnej mogą organizować się w grupy producentów rolnych w celu dostosowania produkcji rolnej do warunków rynkowych, poprawy efektywności gospodarowania, planowania produkcji ze szczególnym uwzględnieniem jej ilości i jakości, koncentracji podaży oraz organizowania sprzedaży produktów rolnych, a także ochrony środowiska naturalnego. Artykuł 3 ustawy określa szereg warunków, które muszą zostać spełnione dla prowadzenia działalności przez grupę producentów rolnych, m.in. zgodnie z ust. 1 pkt 1 wskazanego artykułu grupa musi zostać utworzona przez producentów jednego produktu lub grupy produktów. W art. 4 ustawy określone zostały również wymagania, jakie musi spełniać statut lub umowa, na podstawie których działa grupa. W ramach delegacji zawartej w art. 6 ustawy Minister Rolnictwa i Rozwoju Wsi wydał rozporządzenie z dnia 9 kwietnia 2008 r. w sprawie wykazu produktów i grup produktów, dla których mogą być tworzone grupy producentów rolnych, minimalnej rocznej wielkości produkcji towarowej oraz minimalnej liczby członków grupy producentów rolnych (Dz.U. Nr 72, poz. 424 - uchylone 28 kwietnia 2016 r.). 
wych producentów od dotychczasowych. Wojewódzki Sąd Administracyjny uznał, że wymienione działania zainicjowano w celu stworzenia sztucznych warunków pozwalających na uzyskanie pomocy unijnej. W ich wyniku doszło do decentralizacji produkcji: w miejsce dotychczasowych dwóch producentów pojawiło się pięciu, wykorzystujących potencjał gospodarczy dotychczasowych gospodarstw. Dzięki formalnemu rozdrobnieniu dotychczasowych gospodarstw w obrocie prawnym zaczęło funkcjonować pięć podmiotów, czyli tyle, ile było koniecznych do zawiązania grupy i starania się o wsparcie unijne ${ }^{31}$. Za oczywiste WSA uznał, że w użyczonych nowym producentom indycznikach prowadzona była wcześniej taka sama produkcja. Struktura produkcyjna, członkowska i uwarunkowania związane z powstaniem i prowadzoną działalnością grupy jednoznacznie potwierdzały, że nie została ona utworzona w celu realizacji wskazanych celów tworzenia grup producentów rolnych, a wręcz przeciwnie, świadczyły o kontynuacji działalności i odwrotnym procesie jaki zaszedł w przedmiotowej sprawie.

Sąd uznał, że zaskarżony organ przekonująco wskazał okoliczności obiektywne i subiektywne, które doprowadziły do uznania działań grupy za stworzenie sztucznych warunków i tym samym odrzucił sformułowany zarzut naruszenia art. $11 \mathrm{w}$ zw. $\mathrm{z}$ art. $107 \$ 1$ k.p.a. ${ }^{32}$ Odnosząc się do pozostałych zarzutów: naruszenia art. 6, 7, 8, 80 i $77 \$ 1$ k.p.a., WSA słusznie zauważył, że postępowanie w sprawie przyznania płatności regulowanych ustawą oraz wydanym na jej podstawie rozporządzeniem jest postępowa-

${ }^{31}$ W wyroku z dnia 23 lutego 2017 r., II GSK 102/16 NSA stwierdził, że suma okoliczności faktycznych sprawy (dotyczących zarówno elementów obiektywnych, jak i subiektywnych) uzasadnia stanowisko organów o sztucznym stworzeniu przez A. warunków w celu uzyskania pomocy w sposób sprzeczny z tymi celami. W istocie bowiem utworzenie tej grupy miało na celu obejście przepisów prawa poprzez ominięcie limitów co do liczby członków grupy i stworzenie grupy formalnie spełniającej wszystkie wymogi, jednakże w celu uzyskania korzyści sprzecznej z celami wsparcia. Wskazuje na to sekwencja zamierzonych i przemyślanych działań członków grupy poprzedzających jej zawiązanie, a także powiązania kapitałowe i osobowe między członkami grupy. W związku z utworzeniem grupy tylko pozornie doszło do „połączenia” gospodarstw jej poszczególnych członków, tj. ich areału i potencjału produkcyjnego tego areału. Co istotne, na tych samych gruntach w takim samym cyklu produkcyjnym w systemie płodozmianu była prowadzona produkcja zbóż i rzepaku. W tych okolicznościach nie sposób również uznać, że obiektywny element sprawy, jakim jest realizacja celów systemu wsparcia, może być uznany za spełniony. Ideą tego systemu było bowiem zapewnienie konkurencyjności produkcji gospodarstw niskotowarowych w wyniku konsolidacji mocy produkcyjnej poprzez osiągniecie celów szczegółowych określonych w art. 35 ust. 1 rozporządzenia $\mathrm{nr}$ 1698/2005.

${ }^{32}$ Por. wyrok NSA z dnia 23 lutego 2017 r., II GSK 1745/15 oddalający skargę kasacyjną spółki z o.o. od wyroku WSA w Warszawie z dnia 9 marca 2015 r., V SA/Wa 3307/14; wyrok NSA z dnia 23 lutego 2017 r., II GSK 102/16 oddalający skargę kasacyjną spółki z o.o. od wyroku WSA w Warszawie z dnia 12 października 2015 r., V SA/ Wa 1629/15; wyrok NSA z dnia 23 lutego 2017 r., II GSK 1961/15 oddalający skargę kasacyjną spółki z o.o. od wyroku WSA w Warszawie z dnia 27 kwietnia 2015 r., V SA/ Wa $3249 / 14$. 
niem szczególnym. Z treści art. 21 ustawy z dnia 7 marca 2007 r. o wspieraniu rozwoju obszarów wiejskich $\mathrm{z}$ udziałem środków Europejskiego Funduszu Rolnego na rzecz Rozwoju Obszarów Wiejskich wynika, że z zastrzeżeniem zasad i warunków określonych w przepisach Unii Europejskiej, wskazanych w art. 1 pkt 1 tej ustawy, do postępowań w sprawach indywidualnych rozstrzyganych w drodze decyzji stosuje się przepisy Kodeksu postępowania administracyjnego, chyba że przepisy ustawy stanowią inaczej. Odrębności tego postępowania, w stosunku do ogólnego postępowania administracyjnego, szczegółowo wskazane w ust. 2 art. 21, wyrażają się również $\mathrm{w}$ tym, że jak wynika $\mathrm{z}$ ust. 3 art. 21 , strony oraz inne osoby uczestniczące w postępowaniu są zobowiązane przedstawiać dowody oraz dawać wyjaśnienia co do okoliczności sprawy zgodnie z prawdą i bez zatajania czegokolwiek, a ciężar udowodnienia faktu spoczywa na osobie, która wywodzi z niego skutki prawne ${ }^{33}$.

Tym samym Sąd nie podzielił formułowanych w skardze zarzutów bezprawności w działaniach organu polegających na wzywaniu członków grupy do przedstawiania dokumentów i wyjaśnień mających potwierdzać ich twierdzenia, stwierdzając, że jeśli nie dysponowali takimi dokumentami, swoich twierdzeń nie wykazali. Potwierdził on w uzasadnieniu wyroku, że analiza akt wykazała, iż ustalenia organu znajdują odzwierciedlenie w zgromadzonym materiale dowodowym w sprawie, a ocena tego materiału była prawidłowa, logiczna i w sprawie nie występują zarzucane skargą przekroczenie granic swobodnej oceny materiału dowodowego ani też nieuprawnione wnioski wypływające $z$ tej oceny ${ }^{34}$.

${ }^{33}$ Por. S. Prutis, Dobór instrumentów prawnych służacych wsparciu rozwoju obszarów wiejskich, „Studia Iuridica Agraria” 2009, nr 7, s. 192-203; P. Wojciechowski, Postępowanie dotyczace przyznawania pomocy finansowej $w$ ramach działań objętych Programem Rozwoju Obszarów Wiejskich, „Studia Iuridica Agraria” 2012, nr 10, s. 335-354.

${ }^{34}$ Odmienne wnioski sformułował NSA w wyroku z dnia 9 lutego 2017 r., II GSK 1096/16, wskazując, że w zaskarżonym wyroku z dnia 20 listopada 2015 r., V SA/Wa 2109/15 WSA w Warszawie słusznie uchylił zaskarżoną decyzję Prezesa ARiMR i poprzedzającą ją decyzję dyrektora oddziału regionalnego ARiMR, wskazując organom kierunek prowadzenia postępowania wyjaśniającego. Sąd I instancji za konieczne uznał ustalenie okoliczności subiektywnych w postaci zamiaru uzyskania korzyści przez grupę producentów oraz okoliczności obiektywnych, świadczących o niemożności osiągnięcia określonych w art. 35 ust. 1 rozporządzenia nr 1698/2005 celów wsparcia, gdyż poczynienie tych ustaleń pozwoli na ewentualne postawienie grupie producentów zarzutu sztucznego stworzenia warunków do otrzymania wsparcia i zastosowanie art. 4 ust. 8 rozporządzenia nr 65/2011 W ZW. z art. 35 ust. 1 rozporządzenia nr 1698/2005; por. wyrok NSA z dnia 9 lutego 2017 r., II GSK 1572/15 w sprawie skargi kasacyjnej Prezesa ARiMR od wyroku WSA w Warszawie z dnia 1 kwietnia 2015 r., V SA/Wa 2938/14; wyrok NSA z dnia 28 marca 2017 r., II GSK 1960/15 w sprawie skargi kasacyjnej Prezesa ARiMR od wyroku WSA w Warszawie z dnia 15 maja 2015 r., V SA/Wa 225/15; wyrok NSA z dnia 28 marca 2017 r. uchylający wyrok WSA z dnia 2 marca 2015 r. oddalający skargę (V SA/Wa 2984/14) i przekazujący sprawę do ponownego rozpoznania II GSK 1977/15. Odnośnie do oceny przeprowadzonego przez organy ARiMR 
$\mathrm{W}$ ramach kolejnego bloku tematycznego przedstawione zostanie zagadnienie sztucznego tworzenia warunków do przyznania płatności zalesieniowych. Doskonałym przykładem takiego procederu jest stan faktyczny opisany w wyroku z dnia 18 marca 2015 r., V SA/Wa 2462/14 $4^{35}$. Sprawa dotyczyła pomocy $\mathrm{w}$ ramach działania „Zwiększanie wartości dodanej podstawowej produkcji rolnej i leśnej” objętego programem Rozwoju Obszarów Wiejskich na lata 2007-2013 ${ }^{36}$. Celem tego programu było wsparcie

postępowania dowodowego w sprawach dotyczących omawianej tematyki należy przybliżyć treść wyroku NSA z dnia 28 marca 2017 r., II GSK 138/17 uchylającego zaskarżony wyrok WSA w Warszawie z dnia 13 września 2016 r., V SA/Wa 3555/15 oddalający skargę, i przekazującego sprawę do ponownego rozpoznania przez WSA. W uzasadnieniu tego wyroku NSA zwrócił uwagę, że w utrwalonym orzecznictwie sądów administracyjnych przyjmuje się, iż w postępowaniach w sprawach indywidualnych rozstrzyganych w drodze decyzji administracyjnych na podstawie przepisów ustawy o wspieraniu rozwoju obszarów wiejskich organ nie ma obowiązku aktywnego poszukiwania dowodów, albowiem to na stronie ciąży obowiązek przedstawiania dowodów oraz dawania wyjaśnień co do okoliczności sprawy. Wobec zobowiązania strony do przedstawienia wszystkich dowodów niezbędnych do dokładnego wyjaśnienia stanu faktycznego i załatwienia sprawy, ustawodawca oparł bowiem postępowanie dowodowe w znacznym stopniu na dowodach przedstawionych przez stronę, a tym samym przeniósł ciężar dowodu na osobę, która $\mathrm{z}$ faktu wywodzi skutki prawne. $\mathrm{W}$ istocie więc na stronie ubiegającej się o płatności spoczywa ciężar wykazania, że w sposób rzeczywisty spełnia warunki do ich uzyskania. W odniesieniu do treści art. 21 ust. 3 in fine ustawy o wspieraniu rozwoju obszarów wiejskich nie może jednak umykać z pola widzenia, że to organ, odmawiając płatności, wywodzi skutki prawne z zarzutu tworzenia sztucznych warunków do otrzymania wsparcia i to na organie ciąży obowiązek wykazania tych sztucznych warunków. Ustalenia takie winny zaś w sposób niebudzący żadnych wątpliwości wynikać ze zgromadzonego, a następnie rozpatrzonego przez organy materiału dowodowego, jaki stanowi podstawę rozstrzygnięcia. W przeciwnym wypadku ustalenia organów należy uznać za niekompletne i niewystarczające do wykazania sztucznego stworzenia przez dany podmiot warunków w celu uzyskania korzyści sprzecznych z celami danego systemu wsparcia. NSA, mając na uwadze okoliczności rozpoznawanej sprawy, uznał, że sąd I instancji powinien rozważyć w świetle wskazań zawartych w wyroku Trybunału Sprawiedliwości Unii Europejskiej z dnia 12 września 2013 r., C-434/12 w sprawie Słynczewa, czy organ wywiązał się z konieczności precyzyjnego wykazania, że skarżąca sztucznie stworzyła warunki do otrzymania płatności w rozumieniu art. 4 ust. 8 rozporządzenia nr 65/2011; por. wyrok NSA z dnia 28 marca 2017 r. uchylający zaskarżony wyrok WSA z dnia 24 kwietnia 2014 r., V SA/Wa 3334/14 i przekazujący sprawę do ponownego rozpoznania przez WSA - II GSK 2381/15.

${ }^{35}$ Wyrok utrzymany w mocy na podstawie wyroku NSA z dnia 15 lutego 2017 r., II GSK 1518/15.

${ }^{36}$ Pomoc ta uregulowana została w rozporządzeniu Ministra Rolnictwa i Rozwoju Wsi z dnia 17 października 2007 r. w sprawie poszczególnych warunków i trybu przyznawania pomocy finansowej w ramach działania 123 „Zwiększanie wartości dodanej podstawowej produkcji rolnej i leśnej” objętego programem Rozwoju Obszarów Wiejskich na lata 2007-2013 (tekst jedn.: Dz.U. z 2014 r. poz. 261 ze zm.), wydanym w oparciu o delegację ustawową $\mathrm{z}$ art. 29 ust. 1 pkt 1 ustawy z dnia 7 marca 2007 r. o wspieraniu rozwoju obszarów wiejskich z udzia- 
przedsiębiorczości i rozwijania struktury gospodarczej na obszarach wiejskich, szczególnie poprzez tytułowe zwiększanie wartości dodanej pod-

łem środków Europejskiego Funduszu Rolnego na rzecz Rozwoju Obszarów Wiejskich. Ustawa ta w art. 1 i 2 wskazuje, że odnosi się do zadań i działań określonych rozporządzeniem nr 1698/2005 w zakresie nieokreślonym w tych przepisach Unii Europejskiej i przepisach wydanych w trybie tego rozporządzenia. Wskazane akty stanowią uzupełnienie regulacji prawa unijnego tylko w zakresie przewidzianym przez przepisy prawa unijnego do określenia przez państwo członkowskie. Regulacje prawa unijnego mają pierwszeństwo stosowania przed prawem krajowym. Według art. 2 pkt 1 ustawy przez działanie należy rozumieć środek, o którym mowa w art. 2 lit. d rozporządzenia nr 1698/2005. Rozporządzenie to określa nie tylko priorytety i środki dla rozwoju obszarów wiejskich (art. 1 pkt 4), ale ustanawia ogólne zasady wsparcia obszarów wiejskich, finansowanego z Europejskiego Funduszu Rolnego na rzecz Rozwoju Obszarów Wiejskich (EFFROW) ustanowionego rozporządzeniem nr 1290/2005 (art. 1 pkt 1) i określa cele, do realizacji których ma się przyczynić polityka rozwoju obszarów wiejskich (art. 1 pkt 2). Zgodnie z preambułą rozporządzenia i jej motywem 6 działalność EFFROW oraz operacje, do których Fundusz się przyczynia, muszą być spójne i zgodne z innymi politykami wspólnotowymi oraz z całym prawodawstwem wspólnotowym. Natomiast według motywu 62 tej preambuły w celu zapewnienia skuteczności, uczciwości i trwałego wpływu pomocy z EFFROW powinny istnieć przepisy gwarantujące, że operacje związane $\mathrm{z}$ inwestycjami są trwałe oraz uniemożliwiają korzystanie $\mathrm{z}$ tego funduszu w celu wprowadzenia nieuczciwej konkurencji. Niewątpliwie przepisem krajowym mającym wpływ na zachowanie uczciwej konkurencji mikroprzedsiębiorstw jest powołane wyżej rozporządzenie MRiRW z dnia 17 lipca 2008 r., z którego wynika, że pomoc jest przyznawana i wypłacana do wysokości limitu, który w okresie realizacji programu (a więc w całym okresie 2007-2013) wynosi na jednego beneficjenta $20 \mathrm{mln}$ zł ( $\$ 4$ pkt 5 rozporządzenia). Zgodnie z treścią $\$ 2$ ust. 1 tego rozporządzenia o pomoc może ubiegać się podmiot, który: 1) prowadzi przedsiębiorstwo określone w art. 28 ust. 3 rozporządzenia Rady (WE) nr 1698/2005 z dnia 20 września 2005 r. w sprawie wsparcia rozwoju obszarów wiejskich przez Europejski Fundusz Rolny na rzecz Rozwoju Obszarów Wiejskich (EFRROW) (Dz. Urz. UE L 277 z 21.10.2005, str. 1, z późn. zm.; dalej jako rozporządzenie nr 1698/2005); 2) wykonuje działalność, o której mowa w art. 28 ust. 1 lit. b tiret pierwsze rozporządzenia $\mathrm{nr}$ 1698/2005, w zakresie: a) co najmniej jednego z rodzajów działalności wymienionych w wykazie określonym w załączniku nr 1 do rozporządzenia lub b) przetwórstwa roślin na produkty, które są wykorzystywane na cele energetyczne; 3) nie podlega wykluczeniu z ubiegania się o przyznanie pomocy na podstawie przepisów rozporządzenia nr 1698/2005 oraz przepisów Unii Europejskiej wydanych w trybie tego rozporządzenia lub przepisów odrębnych; 4) jest zdolny do zrealizowania operacji i osiągnięcia jej celu. Ponadto z treści $₫ 3$ ust. 2 rozporządzenia wynika, że pomoc jest przyznawana podmiotowi, który spełnia warunki określone $\mathrm{w} \$ 2$ ust. 1 rozporządzenia i któremu został nadany numer identyfikacyjny w trybie przepisów o krajowym systemie ewidencji producentów, ewidencji gospodarstw rolnych oraz ewidencji wniosków o przyznanie płatności, jeżeli (pkt 2) zostały spełnione inne warunki określone w rozporządzeniu oraz innych przepisach prawa związanych $\mathrm{z}$ realizacją operacji. Natomiast zgodnie z $\$ 4$ ust. 5 rozporządzenia pomoc przyznaje się i wypłaca do wysokości limitu, który w okresie realizacji programu wynosi maksymalnie $20 \mathrm{mln}$ zł na jednego beneficjenta, przy czym wysokość pomocy przyznanej na realizację jednej operacji nie może być niższa niż 100 tys. zł. 
stawowej produkcji rolnej i leśnej (art. 5 ust. 1 pkt 5 ustawy o wspieraniu rozwoju obszarów wiejskich), co wynika z regulacji art. 2 lit. c w zw. z art. 4 w zw. z art. 20 lit. b pkt iii oraz art. 28 rozporządzenia nr 1698/2005, w myśl których wsparcie ukierunkowane na konkurencyjność sektora rolnego i leśnego dotyczy środków mających na celu restrukturyzację i rozwój kapitału rzeczowego i wspieranie innowacji poprzez zwiększanie wartości dodanej produktów rolnych i leśnych. Wsparcia udziela się z tytułu materialnych lub niematerialnych inwestycji, które: a) poprawiają ogólne wyniki przedsiębiorstwa; b) dotyczą: przetwarzania lub obrotu produktami objętymi załącznikiem I do Traktatu, z wyjątkiem produktów rybołówstwa oraz przetwarzania lub obrotu produktami leśnymi, i/lub rozwoju nowych produktów, procesów i technologii związanych z produktami objętymi załącznikiem I do Traktatu, $\mathrm{z}$ wyjątkiem produktów rybołówstwa oraz rozwoju nowych produktów, procesów i technologii związanych z produktami leśnymi, oraz c) spełniają normy wspólnotowe mające zastosowanie do danej inwestycji.

Ponadto z art. 28 ust. 3 wynika wyraźnie, że wsparcie udzielane na mocy art. 28 ust. 1 rozporządzenia nr 1698/2005 w maksymalnej stawce ogranicza się do mikro-, małych i średnich przedsiębiorstw w rozumieniu zalecenia Komisji 2003/361/WE ${ }^{37}$. W $\$ 4$ ust. 5 krajowego rozporządzenia wykonawczego z dnia 17 października 2007 r. przewidziano kwotę 20000000 zł jako górną granicę pomocy przyznawanej na jeden projekt. Ta górna granica ma ważne znaczenie w sprawie, stanowi bowiem zobiektywizowaną okoliczność równej pomocy na realizację jednego pod względem gospodarczym projektu. Sąd zwrócił uwagę, że skoro jeden zgłaszany do pomocy projekt ma być projektem poprawiającym ogólne wyniki przedsiębiorstwa, dotyczącym przetwarzania lub obrotu produktami objętymi załącznikiem I do Traktatu i/lub rozwoju nowych produktów, procesów i technologii związanych z produktami objętymi załącznikiem I do Traktatu, to logiczne jest, że powinien to być projekt jednego zgłaszającego, stanowiący pewną zamkniętą całość gospodarczą dla tego przedsiębiorcy. Przepisy nie wykluczają podmiotu grupowego, ale musi to być podmiot prowadzący wspólną działalność gospodarczą, podmiot ubiegający się o dofinansowanie na podstawie jednego wniosku pomocowego w działaniu o określonym limicie dopuszczalnej pomocy. Sytuacja, w której dwóch lub więcej beneficjentów ubiegałoby się o pomoc na działalność, która w rzeczywistości stanowi jedną całość gospodarczą, jeden, zamknięty, kompletny projekt oferowany na rynku w ramach komplementarnych usług, byłaby działaniem zagrażającym konkurencyjności chronionej powołanymi przepisami, mającym na celu uzyskanie podwójnej czy większej liczby dofinansowania do jednego realnego projektu, z założenia zmierzającym do uzyskania lepszej pozycji finansowej na starcie w prowadzeniu działalności

${ }^{37}$ Dz. Urz. WE L 124, s. 36. 
w warunkach konkurujących ze sobą podmiotów. Nie ulega wątpliwości, że finanse i ich poziom wpływają w sposób bezpośredni i zasadniczy na prowadzenie działalności gospodarczej, na jej rozmiar, obroty, możliwości oferty na otwartym rynku gospodarczym.

Ustawodawca, regulując wsparcie, w żadnym razie nie chciał umożliwić wybranym podmiotom uzyskania silniejszej pozycji rynkowej w porównaniu do innych powstających bądź już działających na tym rynku podmiotów. Przewidując limit dofinansowania, ustawodawca wskazuje bowiem na obiektywnie jednakowe możliwości uzyskania pomocy dla jednego gospodarczego projektu ${ }^{38}$. Zgodnie $\mathrm{z}$ treścią motywu 12 preambuły zalecenia Komisji 2003/361/WE z dnia 6 maja 2003 r. dotyczącego definicji małych i średnich przedsiębiorstw (stanowiącego załącznik I do rozporządzenia Komisji (WE) nr 800/2008 z dnia 6 sierpnia 2008 r.), przy dokonywaniu kwalifikacji danego przedsiębiorstwa należy także wziąć pod uwagę relacje między przedsiębiorstwami a osobami fizycznymi w celu zapewnienia, że tylko przedsiębiorstwa, które naprawdę potrzebują przywilejów wynikających z różnych przepisów lub środków zastosowanych dla ich korzyści, faktycznie z nich skorzystają.

Zdaniem WSA skarżąca nie podważała ustaleń, że weryfikacja wniosku o przyznanie pomocy złożonego przez nią, jak również spółkę GPR Sp. z o. o. w ramach naboru wniosków wykazała, iż powyższe spółki są powiązane ze sobą poprzez ich udziałowców i osoby pełniące funkcje zarządcze, ale jednocześnie wskazywała, że generalnie były to wnioski złożone przez formalnie odrębne podmioty. Sąd podkreślił, iż należy się zgodzić ze skarżącą, że powołanie wielu spółek czy prowadzenie kilku działalności przez tych samych udziałowców bądź wspólników nie narusza samo w sobie żadnych przepisów krajowych czy wspólnotowych. Przepisy rozporządzenia MRiRW z dnia 17 października 2007 r. nie zawierają ograniczenia w zakresie możliwości ubiegania się o wsparcie przez te podmioty. Jednakże, jak zauważył Sąd, w niniejszej sprawie organ prawidłowo ustalił, że prowadzenie działalności przez powiązane spółki, ich powiązania kapitałowe, osobowe i funkcjonalne dało uzasadnione podstawy do stwierdzenia, iż stanowi to próbę obejścia przepisów dotyczących limitu kwoty pomocy, jaka może być przyznana i wypłacona jednemu beneficjentowi w okresie realizacji programu.

Oceniając zgromadzony w sprawie materiał dowodowy, który stanowił podstawę zaskarżonego rozstrzygnięcia, WSA zgodził się ze stanowiskiem skarżonego organu, który wykazał związek istniejący pomiędzy spółkami, wynikający z ich struktury własnościowej, lokalizacji miejsca prowadzonej działalności w ramach jednego naboru wniosków i powiązań kapitałowych. Skarżąca spółka, jak stwierdził skarżony organ, zajmuje się działalnością polegającą na zakupie zboża, a GPR sprzedażą producentom pasz dla zwierząt. Generalnie zakres prowadzonej działalności nie wyklucza

\footnotetext{
${ }^{38}$ Zob. wyrok WSA w Warszawie z dnia 26 września 2014 r., V SA/Wa 966/14.
} 
więc, że działania obydwu beneficjentów mogły się uzupełniać i stanowić jeden profil działania. Poza tym oba podmioty prowadzą działalność na jednej działce ewidencyjnej, a zbyt skarżącej spółce zapewnia GPR (50\%), co świadczy o tym, że obiektywnie ich działalność jest komplementarna i pozwoli na stworzenie de facto jednego przedsiębiorstwa, którego celem będzie produkcja i zbyt zboża, a następnie wykorzystanie go do produkcji pasz dla zwierząt. Będzie to łatwiejsze i uzasadnione ekonomicznie, gdyż działalność obu podmiotów prowadzona będzie na jednej działce ewidencyjnej, tym bardziej że oba podmioty będą zarządzane przez te same osoby. Zdaniem Sądu nie można w związku z tym odmówić zasadności i spójności twierdzeniom o stworzeniu sztucznych warunków.

Odnosząc się do zarzutów zawartych w skardze, WSA wskazał, że nie ma podstawy do uznania, iż rynek zbytu przyjęty dla skarżącej spółki ma charakter przykładowy (hipotetyczny) i że odbiorcą produktów będą inne podmioty niż spółka GPR. Elementem wniosku o dofinansowanie jest biznesplan, w którym wskazano rynek zbytu. Przesłanka zbytu jest badana przy rozpoznawaniu wniosku o dofinansowanie jako element związany z faktyczną możliwością zrealizowania inwestycji. Ta podana przez skarżącą we wniosku o dofinansowanie wskazuje, że spółka GPR będzie znaczącym odbiorcą produktów skarżącego. Oznacza to także, że z kolei działalność tej spółki będzie uzależniona od działalności skarżącej spółki. Okoliczności te świadczą o ekonomicznym powiązaniu pomiędzy tymi podmiotami, dlatego też, zdaniem Sądu, wystarczyło, aby organy uprawdopodobniły, iż możliwe jest wspólne działanie pomiędzy wnioskodawcami w celu osiągnięcia efektu finansowego i gospodarczego, aby można było traktować te wnioski jako uzupełniające się i podlegające ocenie $\mathrm{w}$ przedmiocie ewentualnego stworzenia sztucznych warunków.

Wojewódzki Sąd Administracyjny w analizowanym wyroku zaznaczył, że ARiMR nie negowała możliwości prowadzenia działalności gospodarczej przez obie spółki jako samodzielnych przedsiębiorców. Obowiązujące przepisy, zdaniem Sądu, nie dopuszczają możliwości udzielenia pomocy publicznej tym podmiotom, które sztucznie stworzyły warunki wymagane do otrzymania płatności w celu uzyskania korzyści sprzecznych z celami systemu wsparcia w ramach działania „Zwiększanie wartości dodanej podstawowej produkcji rolnej i leśnej”, w tym odnośnie do uzyskania kwoty przewyższającej możliwe dofinansowanie, co w świetle wniosków o dofinansowanie i przyznanych wcześniej kwot nie budzi wątpliwości. Sąd uznał, że skoro zdaniem organu zachodziło duże prawdopodobieństwo, iż skarżąca wraz z powiązaną spółką stworzyły sztuczne warunki uzyskania pomocy poprzez chęć przysporzenia (przekroczenia) na swoją rzecz limitu pomocy przysługującego jednemu beneficjentowi, to miał on podstawę do wydania rozstrzygnięcia o odmowie udzielenia dofinansowania na mocy wskazanych przepisów. 
Oceny co do tożsamości projektu nie może zmienić okoliczność, że formalnie projekt jest przedstawiany w odrębnych wnioskach, przez odrębne podmioty wskazujące na samodzielność w prowadzeniu działalności gospodarczej i w sporządzeniu formalnie własnego projektu zgłoszonego do dofinansowania. Ocena dokonanych zgłoszeń musi uwzględniać wszystkie okoliczności związane z przedstawianą inwestycją, w tym realność funkcjonowania gospodarczego inwestycji po jej zrealizowaniu z pieniędzy publicznych przyznanych w ramach omawianego dofinansowania. Taka ocena jest dokonywana na użytek udzielenia wnioskowanej pomocy i nie ma nic wspólnego z utrudnianiem czy ograniczaniem swobody w prowadzeniu działalności gospodarczej na rynku krajowym. W ramach swobody gospodarczej można prowadzić działalność gospodarczą w podmiotach dozwolonych prawem. Zdaniem Sądu organ rozstrzygający wniosek skarżącej nie zabrania ani nie uniemożliwia prowadzenia działalności, jeżeli będzie ona finansowana przez przedsiębiorcę ze środków własnych lub kredytowych.

W przypadku wystąpienia o środki publiczne taki podmiot musi spełniać wszystkie warunki przewidziane przepisami regulującymi to dofinansowanie. Nie jest bowiem tak, że samo zgłoszenie wniosku o pomoc wypełnia przesłanki jej udzielenia ${ }^{39}$. Wskazać też należy, że zarówno ustawodawca unijny, jak i krajowy przewidział możliwość dofinansowania, o określonej górnej kwocie, jednego gospodarczego projektu oferowanego na rynku w ramach omawianego działania. Formalne zgłoszenie przez dwa różne podmioty gospodarcze dwóch projektów nie zawsze stanowi o ich odrębności gospodarczej. Tak też było w opisywanej sprawie. Ocena, czy mamy do czynienia $z$ jednym, spójnym gospodarczym projektem inwestycyjnym została pozostawiona organowi. Przewidział to unijny prawodawca, tworząc przepisy nakładające na organy państwa członkowskiego obowiązek dbania o to, aby przy realizacji prawa do omawianej pomocy nie doszło w wyniku sztucznie stworzonych warunków do uzyskania korzyści sprzecznej z celami dofinansowania (art. 4 ust. 8 rozporządzenia nr 65/2011).

Zdaniem Sądu organ słusznie uznał, że przedstawiony przez skarżącą projekt może być elementem jednej większej inwestycji dwu podmiotów ze względu na komplementarność ich przedsięwzięć, powiązania kapitałowe i osobowe oraz miejsce wykonywania działalności gospodarczej przez oba podmioty na jednej działce ewidencyjnej. Nie chodzi tu o jednakowość prowadzonej działalności gospodarczej, ale o jej uzupełniający charakter. Ta komplementarność, wynikająca także z miejsca prowadzonej działalności na jednej działce, uzasadnia twierdzenie, że pod względem ekonomicznym taka działalność wspólna ma rację bytu. Nie ma w takich okolicznościach potrzeby dokonywania zwiększonych nakładów chociażby na transport zboża, wyszukiwania potencjalnych kontrahentów czy przechowywania go

\footnotetext{
${ }^{39}$ Zob. wyrok WSA w Warszawie z dnia 26 września 2014 r., V SA/Wa 966/14.
} 
przez oba podmioty gospodarcze. Skarżąca spółka nie podważyła w skardze ustaleń organu odnoszących się do istnienia powiązań istniejących pomiędzy skarżącą spółką i spółką GPR, wskazując, że ta druga jest wobec tej pierwszej spółką dominującą, jej jedynym właścicielem i że dokonała w związku z tym zsumowania ich potencjałów.

Zdaniem Sądu organ zasadnie przyjął, że tego rodzaju powiązania kapitałowe i osobowe wyraźnie wskazują, iż zamiarem była realizacja jednego przedsięwzięcia, które zostało podzielone pomiędzy poszczególne spółki, przy czym nie bez znaczenia jest to, że skarżąca spółka powstała dopiero w czasie, kiedy możliwe było ubieganie się o dofinansowanie. Tym samym, mając na uwadze przedstawiony we wnioskach spółek, w tym we wniosku skarżącej spółki, zakres przedsięwzięcia inwestycyjnego oraz powiązania kapitałowe i osobowe udziałowców, a także zarządzających tymi spółkami - ocena, że było to działanie skierowane na pozyskanie korzyści poprzez sztuczne stworzenie warunków w celu uzyskania tej korzyści w sposób sprzeczny $\mathrm{z}$ celami wsparcia w rozumieniu art. 4 ust. 8 rozporządzenia nr 65/2011, nie została skutecznie podważona w skardze.

Z uwagi na przyczynę odmowy przyznania pomocy spółce nie mają też znaczenia podnoszone okoliczności dotyczące działalności spółki ani to, czy łącznie oceniana działalność obydwu spółek powoduje czy też nie powoduje przekroczenia wartości granicznych dla mikroprzedsiębiorcy. Istota zagadnienia dotyczyła bowiem tego, czy działania skarżącej spółki wraz z inną spółką, z uwagi na zamiar realizacji określonego przedsięwzięcia oraz powiązanie osobowe i kapitałowe tych spółek, były wystarczające do stwierdzenia, że było to sztuczne stworzenie warunków w celu uzyskania korzyści w sposób sprzeczny z celami prawa unijnego. $Z \$ 4$ ust. 5 rozporządzenia z dnia 17 października 2007 r., który był podstawą prawną zaskarżonego rozstrzygnięcia, wynika, iż maksymalna kwota pomocy dla jednego beneficjenta wynosiła $20000000 \mathrm{zł}$. Celem tej regulacji było umożliwienie uzyskania środków pomocowych jak największej liczbie podmiotów, które spełniały warunki wymagane prawem. Okoliczności tej sprawy wskazywały, iż cytowany wyżej przepis rozporządzenia nie pozwalał na uzyskanie środków pomocowych przez grupy przedsiębiorców powiązanych ze sobą osobowo, kapitałowo oraz planujących wykonać jedno kompleksowe przedsięwzięcie, a korzyści odniosłyby te same osoby działające w ramach tych podmiotów ${ }^{40}$.

Z tych też względów Sąd nie podzielił zarzutów skarżącej spółki odnoszących się do naruszenia wskazywanych w skardze przepisów prawa materialnego wynikających z przepisów prawa krajowego i unijnego. Zwrócił uwagę, że ustalenia organu znajdują odzwierciedlenie w materiale dowodowym zgromadzonym w sprawie, a ocena tego materiału jest prawidłowa i logiczna. W ocenie Sądu przyjęcie przez organy orzekające, że nastąpiło

\footnotetext{
${ }^{40}$ Por. wyrok NSA w Warszawie z dnia 10 marca 2014 r., II GSK 2076/12.
} 
sztuczne stworzenie warunków w celu uzyskania korzyści finansowej, co pozostaje w sprzeczności z celami prawa wspólnotowego i ma na celu ominięcie przepisów, jest w pełni zasadne. Prawidłowo zatem organy te uznały, iż powyższe działanie skarżącej wyczerpało przesłanki art. 4 ust. 8 rozporządzenia nr 65/2011.

Trzecim i ostatnim blokiem tematycznym analizowanym w odniesieniu do zakazu tworzenia sztucznych warunków do przyznania dotacji są płatności obszarowe, górskie i rolnośrodowiskowe. W celu zobrazowania mechanizmu próby obejścia tego zakazu w ramach wskazanego rodzaju płatności przedstawiony zostanie stan faktyczny i prawny sprawy prowadzonej przez WSA w Białymstoku.

W wyroku z dnia 27 maja 2015 r., I SA/Bk 173/15 $5^{41}$ Wojewódzki Sąd Administracyjny w Białymstoku podzielił ustalenia organów ARiMR, które uznały, że skarżący w sposób sztuczny i pozorny stworzył w porozumieniu z W.G. warunki do przyznania pomocy, a otrzymanie w takiej sytuacji przez skarżącego pomocy finansowej oznaczałoby uzyskanie korzyści sprzecznych z celami ${ }^{42}$ systemu wsparcia i doprowadziłoby do naruszenia celów i istoty działania, wynikających $\mathrm{z}$ art. 7 ust. 1 ustawy o płatnościach $\mathrm{w}$ ramach systemów wsparcia bezpośredniego ${ }^{43}$. Sąd stwierdził, że wskazane ustalenia znalazły potwierdzenie w zgromadzonym w sprawie materiale dowodowym, który został oceniony logiczne, a wnioski przekonująco uzasadnione. Uznał, że organy ARiMR wyjaśniły, dlaczego pomimo

${ }^{41}$ Wyrok utrzymany $\mathrm{w}$ mocy na podstawie wyroku NSA z dnia 9 maja 2017 r., II GSK 2377/15.

${ }^{42} \mathrm{~W}$ uzasadnieniu wyroku z dnia 25 sierpnia 2017 r., II GSK 3445/15 NSA, uchylając zaskarżony wyrok WSA we Wrocławiu z dnia 15 maja 2015 r., II SA/Wr 50/15 oraz decyzję organu II instancji, zwrócił uwagę, że podczas ponownego rozpatrywania sprawy konieczne będzie dokładne określenie nie tylko korzyści finansowej, którą miała zamiar osiągnąć skarżąca kasacyjnie, ale również celu płatności, o którą ubiegała się spółka. NSA zarzucił, że ani organy obu instancji, ani też sąd I instancji nie odniosły się do tego zagadnienia, co sprawia, że sprawa nie została rozpoznana wszechstronnie, $\mathrm{z}$ uwzględnieniem wszystkich okoliczności.

${ }^{43}$ Zgodnie $\mathrm{z}$ art. 7 ust. 1 ustawy o płatnościach w ramach systemów wsparcia bezpośredniego rolnikowi przysługuje jednolita płatność obszarowa do będącej w jego posiadaniu w dniu 31 maja roku, w którym został złożony wniosek o przyznanie tej płatności, powierzchni gruntów rolnych wchodzących w skład gospodarstwa rolnego, kwalifikujących się do objęcia tą płatnością zgodnie z art. 124 ust. 2 akapit pierwszy rozporządzenia $\mathrm{nr} 73 / 2009$, jeżeli: 1) posiada w tym dniu działki rolne o łącznej powierzchni nie mniejszej niż określona dla Rzeczypospolitej Polskiej w załączniku nr VII do rozporządzenia nr 1121/2009, z tym że w przypadku zagajników o krótkiej rotacji działka rolna powinna obejmować jednolitą gatunkowo uprawę o powierzchni co najmniej 0,1 ha; 2) wszystkie grunty rolne są utrzymywane zgodnie $\mathrm{z}$ normami przez cały rok kalendarzowy, w którym został złożony wniosek o przyznanie tej płatności; 3a) przestrzega wymogów przez cały rok kalendarzowy, w którym został złożony wniosek o przyznanie tej płatności; 4) został mu nadany numer identyfikacyjny w trybie przepisów o krajowym systemie ewidencji producentów, ewidencji gospodarstw rolnych oraz ewidencji wniosków o przyznanie płatności. 
poprawności formalnej wniosku o płatność, stworzone zostały warunki umożliwiające uzyskanie korzyści sprzecznych z celami systemu wsparcia, a mianowicie zweryfikowały, czy wnioskujący o płatność faktycznie użytkował grunty deklarowane do płatności ${ }^{44}$. Wskazano powiązania między dzierżawcą i wydzierżawiającym grunty oraz podobieństwa w stosowanych przez wydzierżawiającego mechanizmach dzierżawy z innymi osobami, a także wykazano wolę uzyskania korzyści sprzecznej z celami wsparcia poprzez skoordynowane działania zmierzające do obejścia przepisów prawa przez osoby wnioskujące o płatność do poszczególnych wydzierżawionych działek. Z akt sprawy wynikało, że działki rolne zadeklarowane we wniosku skarżący dzierżawił na podstawie umów zawartych w marcu $2011 \mathrm{r}$. z podmiotem reprezentowanym przez W.G. - tj. A. S.A. W umowach tych określono wysokość czynszu dzierżawnego, a skarżący wyraził zgodę, aby wydzierżawiający dokonywał potrąceń wymagalnych świadczeń z należnych mu dopłat bezpośrednich oraz środków przyznanych z innych programów pomocowych. Od maja 2011 r. W.G. był pełnomocnikiem skarżącego do prowadzenia wszelkich czynności i postępowań dotyczących wszystkich działań realizowanych przez organy ARiMR oraz wyraził zgodę na przekazywanie płatności na rachunek bankowy pełnomocnika. Umowy dzierżawy zostały wypowiedziane przez wydzierżawiających pismami z lipca 2013 r. W piśmie z listopada 2013 r. skarżący odwołał zaś pełnomocnictwo udzielone W.G. Wojewódzki Sąd Administracyjny uznał, że powyższe dowody i okoliczności, w połączeniu z analizą zeznań W.G. z maja 2014 r., oświadczenia P.F. z lipca 2014 r. oraz jego zeznań złożonych we wrześniu 2014 r. w charakterze świadka, zeznań skarżącego złożonych we wrześniu 2014 r. oraz weryfikacją innych producentów ubiegających się o przyznanie płatności, którzy dzierżawili grunty rolne od W.G. na podobnych zasadach jak skarżący, potwierdzają wnioski przyjęte przez organy administracyjne.

W ramach analizowanej sprawy ustalono, że skarżący nie prowadził działalności rolniczej w myśl art. 2 lit. c rozporządzenia nr 73/2009, gdyż jego celem nie była produkcja roślinna, a jedynie chęć otrzymania dopłat ${ }^{45}$. Skarżący nie ponosił żadnego ryzyka finansowego jako elemen-

${ }^{44}$ Wojewódzki Sąd Administracyjny w analizowanym wyroku zwrócił uwagę na podkreślany przez organy ARiMR specyficzny aspekt, polegający na tym, że prawo do ich otrzymania wiąże się $\mathrm{z}$ faktycznym korzystaniem $\mathrm{z}$ gruntów. Idea płatności obszarowych wynika ze wspólnotowej polityki wspierania dochodów rolników i dotyczy, co wynika bezpośrednio z prawa wspólnotowego, pomocy finansowej udzielanej tylko tym podmiotom, które są faktycznymi użytkownikami gruntów rolnych. Zob. wyrok NSA z dnia 18 października 2011 r., II GSK 1034/10.

${ }^{45}$ Por. wyrok WSA w Warszawie z dnia 15 grudnia 2016 r., VIII SA/Wa 828/16, utrzymany w mocy przez wyrok NSA z dnia 4 lipca 2017 r., II GSK 1435/17, w którym zawarto m.in. następujące ustalenia: skarżąca spółka nie zatrudniała żadnych pracowników, nie dysponowała zapleczem maszynowym, budynkami gospodarczymi, nadto sama nie wykonywała żadnych prac, zlecając ich wykonanie podmiotowi zewnętrznemu należącemu do P.M. Deklarowane nieruchomości położone 
tu nieodzownego w każdym rodzaju działalności produkcyjnej ${ }^{46}$. W żaden sposób nie przetwarzał zbiorów siana $\mathrm{z}$ deklarowanych do płatności działek rolnych, ponieważ nie prowadził hodowli zwierząt gospodarskich.

są w odległych województwach. Zdaniem WSA w Warszawie w takiej sytuacji nie może być mowy o poprawie konkurencyjności rolnictwa poprzez wspieranie restrukturyzacji, rozwoju i innowacji na terenie, który spółka wskazała we wniosku o przyznanie przedmiotowej płatności. W sprawie stwierdzono również, że firma, z której usług spółka korzystała, zgodnie z przedstawionymi przez nią fakturami, protokołami zleceń wykonania usługi i umową o świadczenie usług ma swoją siedzibę w B., poza terenem upraw zgłoszonych do płatności.

${ }^{46}$ Por. wyrok WSA w Białymstoku z dnia 29 kwietnia 2015 r., I SA/Bk 185/15, utrzymany w mocy przez wyrok NSA z dnia 9 maja 2017 r., II GSK 2373/15_w sprawach dotyczących pomocy finansowej z tytułu wspierania gospodarowania na obszarach górskich i innych obszarach o niekorzystnych warunkach gospodarowania. Sprawy dotyczyły pomocy uregulowanej przez $₫ 2$ rozporządzenia Ministra Rolnictwa i Rozwoju Wsi z dnia 11 marca 2009 r. w sprawie szczegółowych warunków i trybu przyznawania pomocy finansowej w ramach działania „Wspieranie gospodarowania na obszarach górskich i innych obszarach o niekorzystnych warunkach gospodarowania (ONW)" objętego Programem Rozwoju Obszarów Wiejskich na lata 2007-2013 (Dz.U. Nr 40, poz. 329 ze zm.), w brzmieniu obowiązującym w 2013 r., płatność ONW przysługuje rolnikowi w rozumieniu przepisów art. 2 lit. a rozporządzenia nr 73/2009: „1) który podjął zobowiązanie, o którym mowa w: a) art. 14 ust. 2 tiret drugie rozporządzenia Rady (WE) nr 1257/1999 z dnia 17 maja 1999 r. w sprawie wsparcia rozwoju obszarów wiejskich z Europejskiego Funduszu Orientacji i Gwarancji Rolnej (EFOGR) oraz zmieniającego i uchylającego niektóre rozporządzenia, albo b) art. 37 ust. 2 rozporządzenia Rady (WE) nr 1698/2005 z dnia 20 września 2005 r. w sprawie wsparcia rozwoju obszarów wiejskich przez Europejski Fundusz Rolny na rzecz Rozwoju Obszarów Wiejskich (EFRROW); 2) jeżeli łączna powierzchnia działek rolnych w rozumieniu art. 2 pkt 1 rozporządzenia Komisji (WE) nr 1122/2009 z dnia 30 listopada 2009 r. ustanawiającego szczegółowe zasady wykonania rozporządzenia Rady (WE) nr 73/2009 odnośnie do zasady wzajemnej zgodności, modulacji oraz zintegrowanego systemu zarządzania i kontroli w ramach systemów wsparcia bezpośredniego przewidzianych w wymienionym rozporządzeniu oraz wdrażania rozporządzenia Rady (WE) nr 1234/2007 w odniesieniu do zasady wzajemnej zgodności w ramach systemu wsparcia ustanowionego dla sektora wina (Dz. Urz. UE L 316 z 02.12.2009, str. 65), lub ich części, położonych na obszarach górskich i innych obszarach o niekorzystnych warunkach gospodarowania, na których jest prowadzona działalność rolnicza w rozumieniu art. 2 lit. c rozporządzenia $\mathrm{nr} 73 / 2009$, posiadanych w dniu 31 maja roku, w którym został złożony wniosek o przyznanie tej płatności, wynosi co najmniej 1 ha; 3) do położonej na obszarach ONW powierzchni działek rolnych lub ich części, będących w jego posiadaniu w dniu 31 maja roku, w którym został złożony wniosek o przyznanie tej płatności, wynoszącej nie więcej niż 300 ha; 4) jeżeli został mu nadany numer identyfikacyjny w trybie przepisów o krajowym systemie ewidencji producentów, ewidencji gospodarstw rolnych oraz ewidencji wniosków o przyznanie płatności; 5) jeżeli są przestrzegane wymogi i normy określone $\mathrm{w}$ przepisach o płatnościach w ramach systemów wsparcia bezpośredniego, zgodnie z przepisami art. 50a i art. 51 rozporządzenia Rady (WE) nr 1698/2005 z dnia 20 września 2005 r. w sprawie wsparcia rozwoju obszarów wiejskich przez Europejski Fundusz Rolny na rzecz Rozwoju Obszarów Wiejskich (EFRROW)”. 
Nie prowadził też sprzedaży pozyskanych plonów. Cały plon zbierany był maszynami firmy B. i przekazywany tej spółce, która zajmowała się hodowlą bydła. Przeważająca część płatności rolnośrodowiskowych, o które wnioskował skarżący, była zatrzymywana przez wydzierżawiającego grunty (W.G.), wskazanego jednocześnie jako pełnomocnik skarżącego.

Zdaniem Sądu organ odwoławczy skutecznie podważył treść oświadczenia P.F. z lipca 2014 r., wskazującego, że jest rolnikiem prowadzącym działalność rolniczą i że użyczał skarżącemu maszyny do koszenia, zgrabiania i zbioru traw. Zeznając $\mathrm{w}$ charakterze świadka, P.F. wyjaśnił natomiast, że nie posiada własnego gospodarstwa rolnego i nie prowadzi działalności rolniczej na własny rachunek. $Z$ zeznań tych wynikało, że jest zatrudniony w B. Sp. z o.o., a zbiór plonów na gruntach dzierżawionych przez skarżącego odbywał się maszynami stanowiącymi własność tej spółki. Sąd uznał, że organ trafnie zwrócił uwagę na rozbieżności w zeznaniach tego świadka i zeznaniach skarżącego $\mathrm{w}$ odniesieniu do zagospodarowania zebranych płodów oraz prawidłowo ocenił twierdzenia strony w zakresie rozliczenia dzierżawy przedmiotowych gruntów.

Dla oceny zebranych dowodów istotne znaczenie miały powiązania ekonomiczne i personalne występujące w rozpatrywanej sprawie: skarżący zeznał, że jest pracownikiem w jednej z firm prowadzonych przez W.G., a P.F. jest $\mathrm{z}$ kolei pracownikiem spółki B. Wspólnikiem tej spółki jest natomiast B. S.A., której jedynym akcjonariuszem jest W.G. Niewątpliwie zatem W.G. miał wpływ na działalność spółki B., który to podmiot gospodarował całością plonów zebranych z gruntów dzierżawionych przez skarżącego od niego właśnie bądź spółki z nim powiązanej. Nie bez znaczenia była także okoliczność, że W.G. bądź spółka z nim powiązana wydzierżawili grunty rolne na takich samych zasadach jak skarżącemu także czterem innym osobom składającym wnioski o przyznanie płatności na swoje nazwisko.

Z zeznań W.G. złożonych w maju 2014 r. wynikało, że w stosunku do wszystkich wydzierżawiających stosowane były te same zasady i że był ich pełnomocnikiem. Wyjaśnił on, że po wpłynięciu dopłat potrącał kwotę należnego czynszu, a pozostałą część przekazywał dzierżawcy.

W świetle zebranych dowodów było wątpliwe, aby zobrazowany mechanizm stanowił jedynie rozliczenie za dzierżawę gruntów: pożytki z produkcji rolnej dzierżawionego przez skarżącego gruntu czerpała bowiem powiązana z W.G. spółka. Skarżący twierdził, że cały plon przekazywany był spółce B., ale sam uzyskiwał korzyść w postaci części z wnioskowanych płatności, za lata 2011-2012 nieprzekraczającą 10\% pobranych płatności.

Wojewódzki Sąd Administracyjny podkreślił, że skarżony organ zasadnie nie dał wiary powyższym twierdzeniom, uznając, że powyższego mechanizmu opłat nie można wiązać z dochodami z działalności rolniczej, na co wskazuje sposób użytkowania działek zgłoszonych do płatności i powiązania między podmiotem wykonującym zabiegi agrotechniczne 
a podmiotem wydzierżawiającym grunty. Część płatności nie mogło również stanowić dochodu dla skarżącego $\mathrm{z}$ tego względu, iż ich uzyskiwanie wymagałoby dodatkowego rozliczenia podatkowego. Powyższe okoliczności wskazują na takie ułożenie stosunków, które miało skierować płatności do gospodarstwa W.G. lub spółki z nim powiązanej niezgodnie z celami wspierania prowadzenia produkcji rolnej w ramach płatności rolnośrodowiskowych ${ }^{47}$. Sąd słusznie zauważył, że takich samych powodów nie można utożsamiać z nakładami na faktycznie prowadzoną działalność rolniczą nakładów na usługi doradcze czy też na certyfikację produkcji rolniczej. Trafnie, zdaniem Sądu, wywiódł organ, że skarżący podejmował jedynie działania polegające na złożeniu wniosku, opracowaniu planu działalności rolnośrodowiskowej i uzyskaniu certyfikatu działalności rolniczej metodami ekologicznymi na potrzeby uzyskania danej płatności. Pozostałe dowody wskazują zaś, że celem skarżącego nie była produkcja rolna, tylko chęć otrzymania dopłat.

Odnosząc się do twierdzeń skarżącego zawartych w uzupełnieniu odwołania od decyzji z października 2014 r., jakoby zbelowaną trawę kupowali okoliczni rolnicy bezpośrednio z pola, a także, że podczas drugiego pokosu korzystał z usług T.T. i W.W., którzy jednocześnie kupowali od nie-

${ }^{47}$ Por. wyrok WSA w Olsztynie z dnia 22 lutego 2017 r., I SA/Ol 16/17, utrzymany w mocy przez wyrok NSA z dnia 25 sierpnia 2017 r., II GSK 2146/17, w którym podsumowano, że: w świetle materiału dowodowego sprawy bezsporne jest, że w 2009 r. dwie osoby fizyczne zamieszkałe $\mathrm{w}$ (...) pod tym samym adresem, o tym samym nazwisku (ojciec i syn) w krótkim okresie czasu utworzyły cztery spółki z ograniczoną odpowiedzialnością, każda o kapitale zakładowym 5 tys. zł (minimalny kapitał zakładowy). Każda ze spółek miała siedzibę w lokalu mieszkalnym (pokój wynajęty od jednego ze wspólników). W początkowym okresie, tj. do 2012 r., wspólnicy jednocześnie byli członkami zarządu wszystkich czterech spółek. Bezsporne jest, że żadna ze spółek nie dysponowała jakimkolwiek innym majątkiem w momencie jej zawiązania, w szczególności majątkiem, który mógłby służyć działalności rolniczej, którą wskazano w umowie spółki obok szeregu innych rozlicznych rodzajów działalności. W ocenie Sądu już ta okoliczność rodziła uzasadnione wątpliwości co do wpisania (w punktach od 1 do 10) jako przedmiot działalności różnych upraw rolnych chociażby jednej spółki, nie mówiąc o czterech. Zdaniem WSA organ I instancji powołał się na dane z KRS i przedstawił je w uzasadnieniach decyzji, dlatego też słusznie dyrektor ARiMR zaakceptował ustalenia i stanowisko organu I instancji, w szczególności co do istnienia powiązań kapitałowych i osobowych między wszystkimi spółkami. Sąd zwrócił uwagę, że spółka z o.o. co do zasady jest formą, w jakiej wspólnicy, poprzez zawarcie umowy spółki, postanawiają osiągnąć cel zapisany w umowie, w tym co do określonej działalności. Wspólnicy zatem, jako organ spółki - zgromadzenie wspólników - decydują o podstawowych kierunkach działalności, i to oni, poprzez dywidendy, korzystają z dochodów (zysków) spółki. Natomiast drugi organ spółki, tj. zarząd, kieruje działalnością spółki i reprezentuje ją w stosunkach wewnętrznych i na zewnątrz. Zdaniem Sądu nie ulega wątpliwości, że jeżeli te same osoby są wspólnikami czterech spółek i jednocześnie członkami zarządu wszystkich czterech spółek, to nie może być mowy o samodzielności i niezależności każdej z nich i należy stwierdzić, że jest to klasyczny przykład stworzenia formalnych warunków mających pozorować niezależność podmiotów. 
go zebrana trawę, Sąd zgodził się ze stanowiskiem organu, który nie dał wiary tym informacjom, gdyż strona postępowania podczas przesłuchania w siedzibie organu we wrześniu 2014 r. i pod rygorem odpowiedzialności karnej za składanie fałszywych zeznań wskazała, że całość plonów była przekazywana P.F. Mając to na uwadze, organ w sposób uzasadniony uznał, że podział gospodarstwa rolnego o łącznej powierzchni użytków rolnych kwalifikowanych do płatności około 450 ha na pięć około stuhektarowych gospodarstw miał sztuczny charakter, a jedynym powodem takiego stanu rzeczy było uzyskanie korzyści sprzecznych $\mathrm{z}$ istotą płatności. Mechanizm podziału gruntu i dzierżawy mniejszych jego działek sprawił, że doszło do obejścia kryteriów dostępu do pomocy w zakresie maksymalnego limitu pomocy dla jednego wnioskodawcy. Potwierdzeniem tego stały się skrupulatne wyliczenia ${ }^{48}$ przeprowadzone w zaskarżonej do Sądu decyzji, gdzie organ wykazał, że w wyniku takiego podziału gruntów należących do W.G. oraz powiązanej z nim A. S.A. doszło do ominięcia zmniejszeń płatności w ramach systemów wsparcia bezpośredniego.

$\mathrm{W}$ związku z tym, jak wykazał organ, biorąc pod uwagę powierzchnię gruntów rolnych wydzierżawioną od W.G. lub powiązanej z nim spółki i zadeklarowaną do przyznania płatności przez wszystkich pięciu dzierżawców, suma pomniejszeń płatności uzupełniających w oparciu o współczynniki korygujące byłaby mniejsza niż w przypadku ubiegania się o przyznanie płatności przez jednego faktycznego użytkownika wydzierżawionych gruntów do tej samej powierzchni co pięciu poszczególnych wnioskodawców ${ }^{49}$. To zaś przekonuje o sztucznie stworzonych warunkach w rozumieniu art. 30 rozporządzenia nr 73/2009. Zdaniem Sądu organy wszechstronnie rozważyły spełnienie przesłanek zawartych w tym przepisie, zgodnie ze wskazówkami Trybunału Sprawiedliwości UE zawartymi w cytowanym wyżej wyroku.

${ }^{48}$ Wyliczenia oparte zostały na postanowieniach rozporządzenia $\mathrm{nr}$ 1181/2013, rozporządzenia Ministra Rolnictwa i Rozwoju Wsi z dnia 9 marca 2009 r. w sprawie rodzajów roślin objętych płatnością uzupełniającą oraz szczegółowych warunków i trybu przyznawania oraz wypłaty płatności w ramach systemów wsparcia bezpośredniego (Dz.U. Nr 40, poz. 326 ze zm.), rozporządzenia Ministra Rolnictwa i Rozwoju Wsi z dnia 14 listopada 2013 r. w sprawie stawki jednolitej płatności obszarowej za 2013 r. (Dz.U. poz. 1334), rozporządzenia Ministra Rolnictwa i Rozwoju Wsi z dnia 19 listopada 2013 r. w sprawie stawek płatności uzupełniających za 2013 r. (Dz.U. poz. 1360).

${ }^{49}$ Por. wyrok WSA w Białymstoku z dnia 29 kwietnia 2015 r., I SA/Bk 183/15, utrzymany w mocy przez wyrok NSA z dnia 9 maja 2017 r., II GSK 2375/15; wyrok WSA w Białymstoku z dnia 27 maja 2015 r., I SA/Bk 172/15, utrzymany w mocy przez wyrok NSA z dnia 9 maja 2017 r., II GSK 2376/15; wyrok WSA w Białymstoku z dnia 27 maja 2015 r., I SA/Bk 174/15, utrzymany w mocy przez wyrok NSA z dnia 9 maja 2017 r., II GSK 2378/15; wyrok WSA w Warszawie z dnia 25 stycznia 2017 r., VIII SA/Wa 975/16, utrzymany w mocy przez wyrok NSA z dnia 20 czerwca 2017 r., II GSK 1571/17; wyrok WSA w Warszawie z dnia 15 grudnia 2016 r., VIII SA/Wa 773/16, utrzymany w mocy przez wyrok NSA z dnia 4 lipca 2017 r., II GSK 1442/17; wyrok WSA w Warszawie z dnia 26 stycznia 2017 r., VIII SA/Wa 1060/16, utrzymany w mocy przez wyrok NSA z dnia 17 sierpnia 2017 r., II GSK 1704/17. 


\section{Podsumowanie}

Analiza stanów faktycznych i prawnych spraw pozwala nie tylko na zobrazowanie samego procederu wyłudzania płatności, ale także na wskazanie zawiłości postępowań prowadzonych zarówno na poziomie administracyjnym, jak i sądowo-administracyjnym. Sądy i organy ARiMR przy ocenie sztucznego stworzenia warunków nie ograniczały się do sprawdzenia działań samego wnioskodawcy. Powiązania osobowe i kapitałowe dotyczyły nawet kilkudziesięciu beneficjentów. Podmioty posiadały ten sam adres, taki sam lub podobny przedmiot działalności, zostały zarejestrowane w podobnym czasie, reprezentowane były przez osoby ze ściśle określonej grupy osobowej lub kapitałowej. Osoby fizyczne składające oddzielne wnioski zasiadały w zarządach spółek, były wspólnikami w spółkach lub były spokrewnione. O sztucznym podziale gospodarstw świadczyły ponadto: umowy dzierżawy gruntów zawierane pomiędzy osobami fizycznymi a spółkami, w których osoba fizyczna (wydzierżawiający) i prezes zarządu (dzierżawca) to ta sama osoba, wykonywanie zabiegów agrotechnicznych sprzętem będącym własnością jednej osoby lub użytkowanie polegające na zbieraniu plonów przez lokalnych rolników na własne potrzeby, ich maszynami, bez dodatkowych wzajemnych rozliczeń. Charakterystyczne w przypadkach stworzenia sztucznych warunków było także deklarowanie do płatności gruntów położonych w innych niż siedziba gospodarstwa czy spółki, skrajnie odległych województwach.

Potwierdzenie zarzutów stworzenia sztucznych warunków do przyznania płatności uzasadnia odmowę ich przyznania. W celu zobrazowania skali poruszanego zagadnienia przeanalizowano 22e sprawy rozstrzygnięte przez WSA i NSA. Skargi na decyzje prezesa i dyrektorów oddziałów regionalnych ARiMR oddalono w 18 sprawach, a w 3 uchylono i przekazano do ponownego rozpoznania. Skargi kasacyjne w badanych sprawach NSA w 2017 r. oddalił w 18 sprawach, natomiast w 4 uchylił wyroki WSA i decyzje Prezesa i dyrektorów oddziałów regionalnych ARiMR.

\section{Bibliografia}

Adamiak B., Forma zakończenia postępowania wstępnego organu odwoławczego [w:] B. Adamiak, J. Borkowski, Kodeks postępowania administracyjnego. Komentarz, Warszawa 2006, s. 602-603.

Adamiak B., Obowiązek organu administracji publicznej rozpatrzenia całego materiału dowodowego [w:] Kodeks postępowania administracyjnego. Komentarz, Warszawa 2006.

Bieluk J., Łobos-Kotowska D.J., Komentarz do art. 3 ustawy o płatnościach $w$ ramach systemów wsparcia bezpośredniego [w:] Ustawa o płatnościach $w$ ramach systemów wsparcia bezpośredniego. Komentarz, LEX 2008.

Daniel P., Prawa i obowiązki organu administracji w postępowaniu sądowoadministracyjnym, Wrocław 2014. 
Iserzon E., Starościak J., Kodeks postępowania administracyjnego. Komentarz (teksty, wzory i formularze), Warszawa 1970.

Jaśkowska M., Wróbel A., Komentarz aktualizowany do Kodeksu postępowania administracyjnego, LEX 2015.

Kukuła Z., Karnoprawna ocena płatności bezpośrednich w polskim rolnictwie. Glosa do postanowienia z dnia 19 maja 2011 r. (I KZP 3/11), „Przegląd Sądowy” 2012, nr 1, s. 126-131.

Martysz C., Komentarz do art. 77 Kodeksu postępowania administracyjnego [w:] G. Łaszczyca, C. Martysz, A. Matan, Kodeks postępowania administracyjnego. Komentarz, t. 1, Komentarz do art. 1-103, LEX 2010.

Peisert M., Szczególne postępowanie administracyjne w sprawach o przyznanie płatności w ramach systemów wsparcia bezpośredniego rolnictwa-zarys problematyki, „Zeszyty Naukowe Sądownictwa Administracyjnego” 2011, nr 1 (34), s. 37-48.

Prutis S., Dobór instrumentów prawnych służących wsparciu rozwoju obszarów wiejskich, „Studia Iuridica Agraria” 2009, nr 7, s. 192-203.

Skrzydło W., Komentarz do art. 184 Konstytucji Rzeczypospolitej Polskiej [w:] Konstytucja Rzeczypospolitej Polskiej. Komentarz, Warszawa 2013.

Stoksik J., Wybrane zagadnienia ochrony interesów finansowych Unii Europejskiej w dziedzinie wspólnej Polityki Rolnej, „Studia Iuridica Agraria” 2012, t. X, s. $436-439$.

Strzelecki M., O kryminalistycznych aspektach wyłudzania płatności bezpośrednich i uzupetniających w świetle badań aktowych, „Prokuratura i Prawo” 2014, nr 6, s. $148-166$.

Wojciechowski P., Odpowiedzialność administracyjna i karna beneficjentów pomocy z Programu Rozwoju Obszarów Wiejskich, „Studia Iuridica Agraria” 2012, t. X, s. 290-291.

Wojciechowski P., Postępowanie dotyczace przyznawania pomocy finansowej $w$ ramach działań objętych Programem Rozwoju Obszarów Wiejskich, „Studia Iuridica Agraria" 2012, nr 10, s. 335-354.

\section{Orzecznictwo}

Wyrok TS z dnia 21 lipca 2005 r. w sprawie C-515/03, Eichsfelder Schlachtbetrieb GmbH v. Hauptzollamt Hamburg-Jonas, ECR 2005, nr 7B, s. I-7355.

Wyrok TS z dnia 11 stycznia 2007 r. w sprawie C-279/05, Vonk Dairy Products BV v. Productschap Zuivel, ECR 2007, nr 1A, s. I-239.

Wyrok TS z dnia 12 września 2013 r. w sprawie C-434/12, Stynczewa siła EOOD v. Izpylnitelen direktor na Dyrżawen fond "Zemedelie” - Razplasztatelna agencija, ZOTSiS 2013, nr 9, s. I-546.

Wyrok NSA z dnia 18 października 2011 r., II GSK 1034/10, CBOSA.

Wyrok NSA z dnia 10 marca 2014 r., II GSK 2076/12, CBOSA.

Wyrok NSA z dnia 11 marca 2015 r., II GSK 134/14, CBOSA.

Wyrok NSA z dnia 4 września 2015 r., II GSK 1636/14, CBOSA.

Wyrok NSA z dnia 28 października 2015 r., II GSK 1884/14, CBOSA.

Wyrok NSA z dnia 12 stycznia 2017 r., II GSK 1299/15, CBOSA.

Wyrok NSA z dnia 9 lutego 2017 r., II GSK 1572/15, CBOSA.

Wyrok NSA z dnia 9 lutego 2017 r., II GSK 1096/16, CBOSA. 
Wyrok NSA z dnia 15 lutego 2017 r., II GSK 1518/15, CBOSA. Wyrok NSA z dnia 23 lutego 2017 r., II GSK 102/16, CBOSA. Wyrok NSA z dnia 23 lutego 2017 r., II GSK 1745/15, CBOSA. Wyrok NSA z dnia 23 lutego 2017 r., II GSK 1961/15, CBOSA. Wyrok NSA z dnia 23 lutego 2017 r., II GSK 102/16, CBOSA. Wyrok NSA z dnia 28 marca 2017 r., II GSK 138/17, CBOSA. Wyrok NSA z dnia 28 marca 2017 r., II GSK 1960/15, CBOSA. Wyrok NSA z dnia 28 marca 2017 r., V SA/Wa 2984/14, CBOSA. Wyrok NSA z dnia 9 maja 2017 r., II GSK 2373/15, CBOSA. Wyrok NSA z dnia 9 maja 2017 r., II GSK 2375/15, CBOSA. Wyrok NSA z dnia 9 maja 2017 r., II GSK 2376/15, CBOSA. Wyrok NSA z dnia 9 maja 2017 r., II GSK 2377/15, CBOSA. Wyrok NSA z dnia 9 maja 2017 r., II GSK 2378/15, CBOSA. Wyrok NSA z dnia 20 czerwca 2017 r., II GSK 1571/17, CBOSA. Wyrok NSA z dnia 4 lipca 2017 r., II GSK 1435/17, CBOSA. Wyrok NSA z dnia 4 lipca 2017 r., II GSK 1442/17, CBOSA. Wyrok NSA z dnia 6 lipca 2016 r., II GSK 511/15, CBOSA. Wyrok NSA z dnia 17 sierpnia 2017 r., II GSK 1704/17, CBOSA. Wyrok NSA z dnia 25 sierpnia 2017 r., II GSK 2146/17, CBOSA. Wyrok NSA z dnia 25 sierpnia 2017 r., II GSK 3445/15, CBOSA. Wyrok WSA w Gdańsku z dnia 25 czerwca 2013 r., I SA/Gd 391/13, CBOSA. Wyrok WSA w Łodzi z dnia 14 stycznia 2014 r., III SA/Łd 1007/13, CBOSA. Wyrok WSA w Krakowie z dnia 18 lutego 2014 r., III SA/Kr 778/13, CBOSA. Wyrok WSA w Krakowie z dnia 12 sierpnia 2014 r., III SA/Kr 6/14, CBOSA. Wyrok WSA w Warszawie z dnia 26 września 2014 r., V SA/Wa 966/14, CBOSA. Wyrok WSA w Warszawie z dnia 9 marca 2015 r., V SA/Wa 3307/14, CBOSA. Wyrok WSA w Warszawie z dnia 1 kwietnia 2015 r., V SA/Wa 2938/14, CBOSA. Wyrok WSA w Warszawie z dnia 27 kwietnia 2015 r., V SA/Wa 3249/14, CBOSA. Wyrok WSA w Białymstoku z dnia 29 kwietnia 2015 r., I SA/Bk 183/15, CBOSA. Wyrok WSA we Wrocławiu z dnia 6 maja 2015 r., III SA/Wr 844/14, CBOSA. Wyrok WSA w Warszawie z dnia 15 maja 2015 r., V SA/Wa 225/15, CBOSA. Wyrok WSA we Wrocławiu z dnia 15 maja 2015 r., II SA/Wr 50/15, CBOSA. Wyrok WSA w Białymstoku z dnia 27 maja 2015 r., I SA/Bk 172/15, CBOSA. Wyrok WSA w Białymstoku z dnia 27 maja 2015 r., I SA/Bk 174/15, CBOSA. Wyrok WSA w Warszawie z dnia 12 października 2015 r., V SA/Wa 1629/15, CBOSA.

Wyrok WSA w Warszawie z dnia 20 listopada 2015 r., V SA/Wa 2109/15, CBOSA. Wyrok WSA w Olsztynie z dnia 3 grudnia 2015 r., I SA/Ol 639/15, CBOSA. Wyrok WSA w Gdańsku z dnia 9 grudnia 2015 r., I SA/Gd 1426/15, CBOSA. Wyrok WSA w Rzeszowie z dnia 7 marca 2016 r., I SA/Rz 1100/15, CBOSA. Wyrok WSA w Warszawie z dnia 15 grudnia 2016 r., VIII SA/Wa 773/16, CBOSA. 
Wyrok WSA w Warszawie z dnia 15 grudnia 2016 r., VIII SA/Wa 828/16, CBOSA. Wyrok WSA w Warszawie z dnia 25 stycznia 2017 r., VIII SA/Wa 975/16, CBOSA. Wyrok WSA w Warszawie z dnia 26 stycznia 2017 r., VIII SA/Wa 1060/16, CBOSA. Wyrok WSA w Olsztynie z dnia 22 lutego 2017 r., I SA/Ol 16/17, CBOSA.

Streszczenie

Z treści rozporządzenia nr 2988/95 z dnia 18 grudnia 1995 r. w sprawie ochrony interesów finansowych Wspólnot Europejskich wynika, że prawo unijne nakłada na Komisję Europejską i państwa członkowskie obowiązek badania, czy środki z budżetu Unii są wykorzystywane zgodnie z ich przeznaczeniem. Państwa członkowskie UE zobligowano do prowadzenia postępowań sprawdzających, czy nie zostały stworzone sztuczne warunki w celu uzyskania korzyści sprzecznych z celami wsparcia. Podstawą takich działań były przepisy określone w rozporządzeniu nr 73/2009 oraz w rozporządzeniu nr 65/2011. Analogiczne rozwiązania zostały zawarte w aktualnie obowiązujących rozporządzeniach Parlamentu Europejskiego i Rady nr 1306/2013 oraz 1307/2013. W artykule autor podjął próbę zdefiniowania pojęcia sztucznego tworzenia warunków do przyznania płatności, a także przedstawił stany faktyczne i prawne spraw, które pozwoliły nie tylko zobrazować sam proceder wyłudzania płatności, ale także wskazać skomplikowany i zawiły charakter postępowań prowadzonych na poziomie administracyjnym i sądowo-administracyjnym.

Słowa kluczowe: sztuczne warunki, dotacje unijne, wyłudzenia funduszy unijnych, agencja płatnicza, ARiMR

\title{
Rulings of Administrative Courts in Cases Concerning the Artificial Creation of Conditions Required for Obtaining Payments from the Agency for Restructuring and Modernisation of Agriculture
}

\begin{abstract}
It transpires from Council Regulation (EC, EURATOM) No 2988/95 of 18 December 1995 on the protection of the European Communities financial interests (OJ L 312, 23.12.1995, p. 1-4, as amended) that EU law requires the European Commission and the Member States to examine whether funds from the EU budget are used as intended. EU Member States are obliged to conduct verification proceedings whether artificial conditions have not been created required for obtaining benefits which contradict the objectives of such support. The basis for the aforementioned activities were provisions of Council Regulation (EC) No 73/2009 and Commission Regulation (EU) No 65/2011. Similar solutions are included in the Regulations of the European Parliament and of the Council (EU) No 1306/2013 and 1307/2013 currently in force. In this article, the author makes an attempt to define the term 'artificial creation of the conditions required for obtaining payments' as well as to present the facts and legal status of cases in question, in order to not just illustrate the practice of payment extortion but also indicate the complex and complicated nature of proceedings carried out by administrative authorities and courts.
\end{abstract}

Keywords: artificial conditions, EU subsidies, EU fund extortion, payment agency, ARMA 